\title{
Utilization of Eco-Friendly Waste Generated Nanomaterials in Water-Based Drilling Fluids; State of the Art Review
}

\author{
Rabia Ikram ${ }^{1, *}$, Badrul Mohamed Jan ${ }^{1, *}$, Akhmal Sidek ${ }^{2}$ and George Kenanakis ${ }^{3, *(D)}$ \\ 1 Department of Chemical Engineering, University of Malaya, Kuala Lumpur 50603, Malaysia \\ 2 Petroleum Engineering Department, School of Chemical and Energy Engineering, Faculty of Engineering, \\ Universiti Teknologi Malaysia, Johor Bahru 81310, Malaysia; akhmalsidek@utm.my \\ 3 Institute of Electronic Structure and Laser, Foundation for Research and Technology-Hellas, N. Plastira 100, \\ Vasilika Vouton, GR-700 13 Heraklion, Greece \\ * Correspondence: raab@um.edu.my (R.I.); badrules@um.edu.my (B.M.J.); gkenanak@iesl.forth.gr (G.K.)
}

Citation: Ikram, R.;

Mohamed Jan, B.; Sidek, A.; Kenanakis, G. Utilization of Eco-Friendly Waste Generated Nanomaterials in Water-Based Drilling Fluids; State of the Art Review. Materials 2021, 14, 4171. https://doi.org/10.3390/ma14154171

Academic Editors: Sergei Kulinich, Valery A. Svetlichnyi, Aleksandr Kuchmizhak and Mitsuhiro Honda

Received: 8 June 2021

Accepted: 24 July 2021

Published: 27 July 2021

Publisher's Note: MDPI stays neutral with regard to jurisdictional claims in published maps and institutional affiliations.

Copyright: (C) 2021 by the authors Licensee MDPI, Basel, Switzerland. This article is an open access article distributed under the terms and conditions of the Creative Commons Attribution (CC BY) license (https:// creativecommons.org/licenses/by/ $4.0 /)$.

\begin{abstract}
An important aspect of hydrocarbon drilling is the usage of drilling fluids, which remove drill cuttings and stabilize the wellbore to provide better filtration. To stabilize these properties, several additives are used in drilling fluids that provide satisfactory rheological and filtration properties. However, commonly used additives are environmentally hazardous; when drilling fluids are disposed after drilling operations, they are discarded with the drill cuttings and additives into water sources and causes unwanted pollution. Therefore, these additives should be substituted with additives that are environmental friendly and provide superior performance. In this regard, biodegradable additives are required for future research. This review investigates the role of various bio-wastes as potential additives to be used in water-based drilling fluids. Furthermore, utilization of these waste-derived nanomaterials is summarized for rheology and lubricity tests. Finally, sufficient rheological and filtration examinations were carried out on water-based drilling fluids to evaluate the effect of wastes as additives on the performance of drilling fluids.
\end{abstract}

Keywords: waste derivatives; rheological properties; nanomaterials; graphene; drilling fluids

\section{Introduction}

Drilling operations are conducted to obtain oil and gas from natural reservoirs deep underground [1]. To facilitate the extraction of hydrocarbons from the ground, a deep hole is drilled to form a wellbore. The use of drilling fluids is an important factor in the drilling process, and these fluids play many roles, such as to assist in removal of drill cuttings and formation pressure control $[2,3]$. There are viable chemical additives used in the drilling fluid that have shown the desired features. However, these additives are non-biodegradable and environmentally hazardous [4]. As a result, researchers have sought to identify alternate additives that are environmentally friendly, biodegradable, and sustainable, while also maintaining the properties of efficient drilling fluids [5].

Drilling fluids must address several challenges encountered during the drilling process. For instance, the drilling structures erected during the process are made of metal, and are thus susceptible to corrosion, which in turn affects the overall drilling operation [6]. A drilling fluid additive that possesses good corrosion inhibition can efficiently address this issue. Another challenge is the excessive circulation loss of fluids into the filtrate medium, which is relatively expensive. To address this problem, a drilling fluid additive should promote good control of the circulation, and of mud cake formation and thickness [7]. Wellbore collapse also may occur due to the interaction and reaction of drilling fluids with formation fluids. The drilling fluid must contain an additive that forms a mud cake with a suitable thickness to ensure that the pipe does not become stuck and to maintain the wellbore stability [8]. 
Other possible scenarios in drilling operations include equipment failure during wellbore completion. Wellbore completion is the process of preparing a wellbore before the production stage, to ensure that the desired hydrocarbons flow out of the formation into the wellbore, and then out [9]. In this situation, a drilling fluid requires additives that are able to control the well and to prevent any significant damage until the equipment can be repaired [10]. Another vital aspect of a drilling fluid is its ability to control $\mathrm{pH}$, rheology, and, in particular, the plastic viscosity, yield point, and gel strength. $\mathrm{pH}$ affects the dispersion process and can greatly affect the physical properties of the drilling mud, such as the properties of the filter cake [11].

Sharma et al. observed that tamarind gum and polyanionic cellulose showed better rheological properties and filtrate loss control performance in an oil well, and also significantly reduced formation damage [12]. Meng et al. evaluated the performance of carbon ash as an additive in comparison to a rheological modifier. Carbon ash showed a superior performance, displaying better rheological properties, satisfactory filtrate loss control, and improved wellbore stability in water-based drilling fluids [13]. Moreover, Omotioma et al. found that cashew and mango extract improved corrosion resistance of water-based drilling fluids, proving that these materials are good corrosion inhibitors, and concluded that the use of extracts of plant leaves boosted the performance of additives [14]. Similarly, Al-Hameedi et al. identified that fibrous food waste material was environmentally friendly and improved the performance of water-based drilling fluids in terms of a wide range of factors, such as better $\mathrm{pH}$ control, fluid loss control, mud cake thickness control, and rheological properties [15]. In addition, Al-Hameedi et al. found that biodegradable grass powder (GP) in comparison to starch, which is a commonly used additive, was batter able to control fluid circulation loss. Although starch showed better rheological properties than GP, this indicates that grass can be used in a supporting capacity in combination with starch to provide a more environmentally friendly additive [16].

Furthermore, Ismail et al. established that henna leaf extract and hibiscus leaf extract enhanced rheology and filtration properties of water-based drilling fluid in comparison to a common additive used in the industry [17]. Oseh et al. also investigated henna leaf extract in terms of its efficiency in transporting cuttings during drilling operations, and showed that henna leaf was effective, and had upgraded rheology and filtration properties under thermal aging conditions [18].

The drilling industry currently uses many additives that provide satisfactory drilling fluid performance. However, these materials have been found to be hazardous, either to the workforce operating on the site or to the environment. Substantial research has been conducted on possible alternative drilling fluid additives that fulfill two conditions: first, that the additive provides the properties required of drilling fluids; and second, that it is environmentally friendly, biodegradable, and sustainable. This paper reviews the research undertaken using various environmentally friendly waste-generated additives in water-based drilling fluids. In particular, the role of these additives on rheological properties, such as plastic viscosity, yield point, gel strength, filtrate loss, and mud cake thickness, is evaluated. Additionally, as a noteworthy aspect of drilling fluids, the impact of various nanomaterials as additives in lubricity tests us summarized.

\section{Drilling Fluids and Rheological Properties}

The principal functions of drilling fluids include removal of drill cuttings and cleaning of the wellbore, lubricating and cooling the drill bit and string, maintaining wellbore formation, and preventing well blowout $[19,20]$. Thus, the drilling fluid plays a significant role in the upstream oil and gas industry. As a major success factor of drilling processes, the properties of drilling fluids are constantly monitored and adjusted as recommended by the American Petroleum Institute (API) Recommended Practice 13B-1 for WBDF and Recommended Practice 13B-2 for OBDF. Based on API Recommended Practice 13B-1, the International Organization for Standardization (ISO) has prepared and outlined the ISO 101,414 under the general title of Petroleum and Natural Gas Industries-Field Testing 
of Drilling Fluids (API, 2009) [21]. ISO 10,414 outlines the standard procedures to regularly determine and monitor the mud properties to ensure maximum drilling performance. These procedures are improved and periodically revised with the emergence of newer studies and developments.

\subsection{Mud Density or Weight}

The mud density or weight is an important property of drilling fluids that functions to improve wellbore stability and maintain formation pressure. According to Das and Chatterjee [22], low mud density can lead to shear failure of rocks, known as a borehole breakout, which subsequently collapses the wellbore. However, Ebikapaye et al. [23] reported the possible loss of circulation, decrease in rate of penetration, and formation damage due to excessive mud density values. Thus, researchers have worked to develop a reliable route, i.e., the PSO-ANN model, to estimate the most suitable density of drilling fluids under HTHP wellbore conditions [24].

\subsection{Plastic Viscosity}

Viscosity measures the internal resistance of drilling fluids, whereas PV is the flow resistivity caused by friction between the solid particulates in drilling fluids and fluid layers [25]. PV is dependent on the viscosity of the base fluids, i.e., water and oil, and the concentration of solids. In short, an increase in mud weight or solid content in drilling fluids results in higher PV, which is undesirable because it lowers the drilling speed. The adverse effects caused by PV have been reduced by the addition of water or a thinning additive [26].

\subsection{Yield Point}

YP is defined as the measured degree of shear thinning performance of non-Newtonian drilling fluids. It is the ability to carry drill cuttings in suspension while circulating in the wellbore and out of the annulus. Hence, drilling problems such as differential sticking can be prevented [27]. According to Maiti et al., as the solid additive particles reduce in size, the YP increases [28]. This is due to the increased attractive forces between solid particles which enhance the carrying capacity of drill cuttings and cleans the wellbore.

\subsection{Gel Strength}

Gel strength (GS) measures the forces of attraction between particles in static conditions, unlike YP which measures them in dynamic conditions [29]. Therefore, gel strength refers to the ability to suspend drill cuttings during connections or other static conditions. As it increases over time, more pressure is required to overcome the accumulated gel strength and initiate the circulation [30].

\subsection{Filtrate Loss and Mud Cake Thickness}

Filtration or fluid loss measures the amount of liquid that permeates a solid mud cake formation. According to previous researchers [31], drilling fluids invade well formations in response to the greater hydrostatic pressure of fluids compared to the pore pressure. This leads to the formation of mud cakes as the pores are filled with suspended solids from the drilling mud. Consequently, the rate of filtrate loss and mud cake thickness decreases as solid concentration in drilling fluids increases. Both filtration rate and mud cake thickness are monitored properties of drilling fluids. This is because to high filtrate loss and mud cake thickness could potentially lead to sticking of the differential pipe [32]. An exceptional mud cake possesses extremely low permeability while being equally thin, tough, and compressible. Filtration control is costly due to requiring many control factors, such as concentration of drilling fluids, size and type of suspended solids, concentration of fluid loss control (FLC) additives, and thermal stability of the system [33]. 


\section{Waste Derivatives in Drilling Fluids}

\subsection{Emergence of Waste Materials in the Environment}

The global population, which is currently 7.8 billion and growing at $1.1 \%$ per year, relies on the consumption of the Earth's natural resources [34]. Waste materials are unusable materials that have exceeded their use and been discarded. Unfortunately, an effect of this continued consumption is the proliferation in waste materials of all varieties, as shown in Figure $1[35]$.

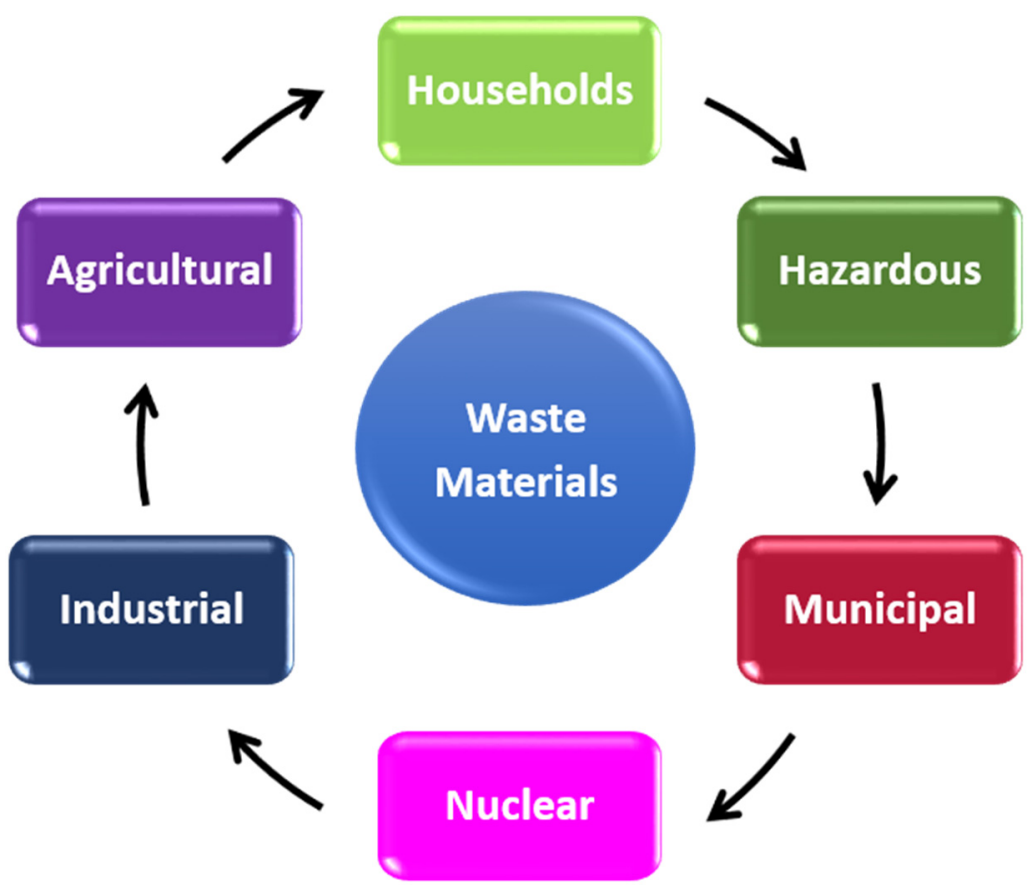

Figure 1. Production of various types of waste.

Waste material includes municipal solid waste (MSW), which comprises common items consumed and discarded by the public, and represents the fastest growing form of waste due to its prevalence in urban society [36]. In a review of solid waste management, Hoornweg and Bhada-Tata estimated that, by 2025, MSW will increase to around $1.42 \mathrm{~kg} /$ capita/day ( 2.2 billion tonnes per year), generated by 4.3 billion urban residents. The authors also estimated that 1.8 million tonnes of MSW would be generated daily in Asia [37,38].

Other types of waste are produced by a range of sources, including domestic and commercial; ash; animals; biomedical and construction industries; and sewers. These wastes may comprise industrial solid waste, biodegradable and non-biodegradable waste, and hazardous waste [39].

Some of these types of waste pose a serious threat to the environment and human health. Clinical waste, which is produced by medical clinics, hospitals, and laboratories, carries the risk of infection and may spread disease if not appropriately managed [40,41].

Electrical and electronic waste (E-waste), from electronic equipment such as cables, wires, cords, and batteries, releases dangerous substances, and thus causes serious harm to those who contact it, particularly workers in the recycling industry [42,43]. Additionally, waste management requires recycling of hazardous waste by various approaches, as presented in Figure 2. 


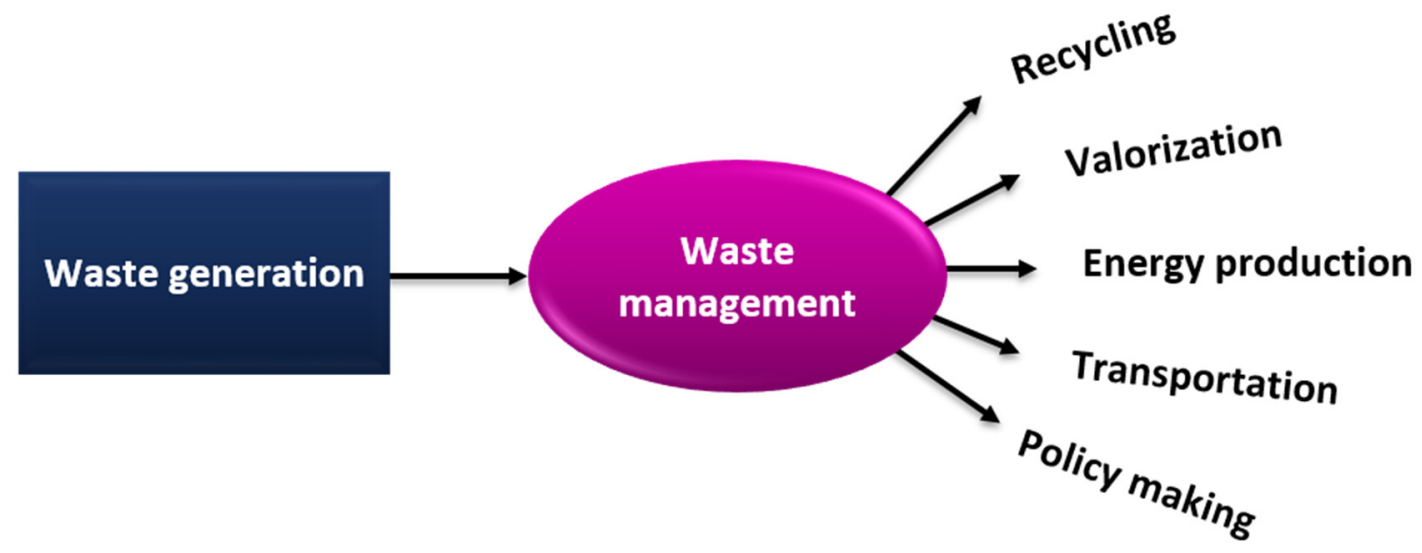

Figure 2. Strategies for recycling of waste materials.

Food waste is a major global issue that is caused by factors including poor food processing operations and management, inadequate household planning of food consumption, and over preparation of food in the food and beverage industry [44,45]. Nevertheless, the problem of food wastage may be meaningfully addressed if the waste can be utilized and reapplied to different applications. The accumulation of wasted food in landfills results in the formation of methane gas and further pollution of the air $[46,47]$.

\subsection{Waste Materials in Drilling Fluids}

A significant amount of research has been conducted regarding the use of food waste in the oil and gas drilling industry [48]. For instance, Al-Hameedi et al. investigated the use of mandarin peel powder (MPP) in an eco-friendly fluid additive, as an alternative to non-biodegradable additives that harm the environment. They utilized MPP as an eco-friendly alternative fluid additive in comparison to a reference polymer, PAC-LV. The MPP additive yielded better outcomes because it was able to significantly lower the $\mathrm{pH}$ and reduce the fluid circulation loss with a low concentration of the powder. Thus, MPP was shown to be a good additive for lowering the $\mathrm{pH}$, viscosity control, and reducing circulation loss. This study encouraged the use of food waste as a suitable alternative to the non-biodegradable chemicals that are currently used in the drilling industry [49].

Furthermore, Al-Hameedi et al. recognized that grass, hay, and palm leaves are also viable candidates. The study verified that food waste can be repurposed to promote an environmentally friendly operation of the oil and gas drilling industry [50]. Figure 3 represents the preparation of food waste as an additive for application in water-based drilling fluids.
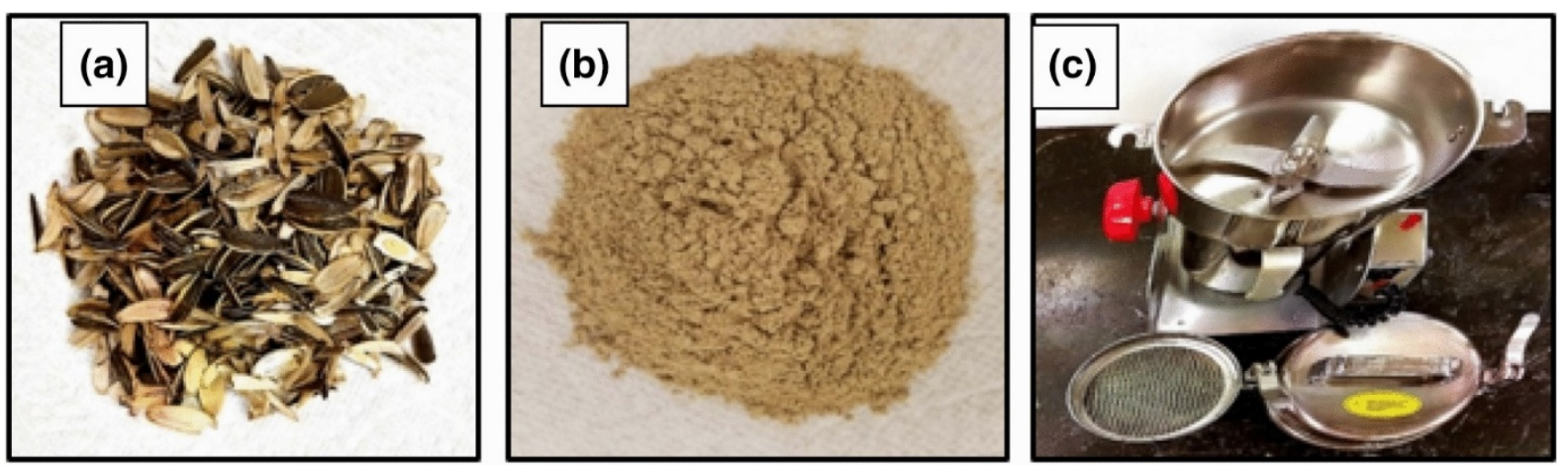

Figure 3. (a) Black sunflower shell raw waste converted into (b) powdered form using (c) a food processor [51].

The oil and gas drilling industry uses additives in drilling fluids for a variety of uses, such as $\mathrm{pH}$ control, and to provide rheological properties, such as plastic viscosity, gel strength, and yield point [52,53]. These additives must also address issues such as 
circulation loss control, wellbore integrity, wellbore completion, and inhibition of corrosion to ensure a smooth drilling operation [54]. However, at present, the chemicals used for these purposes are non-biodegradable and can cause significant negative effects on the environment [55]. A sustainable solution would use chemicals that are biodegradable and do not cause any environmental damage, while simultaneously providing the desired properties of a good drilling fluid, as presented in Figure 4.

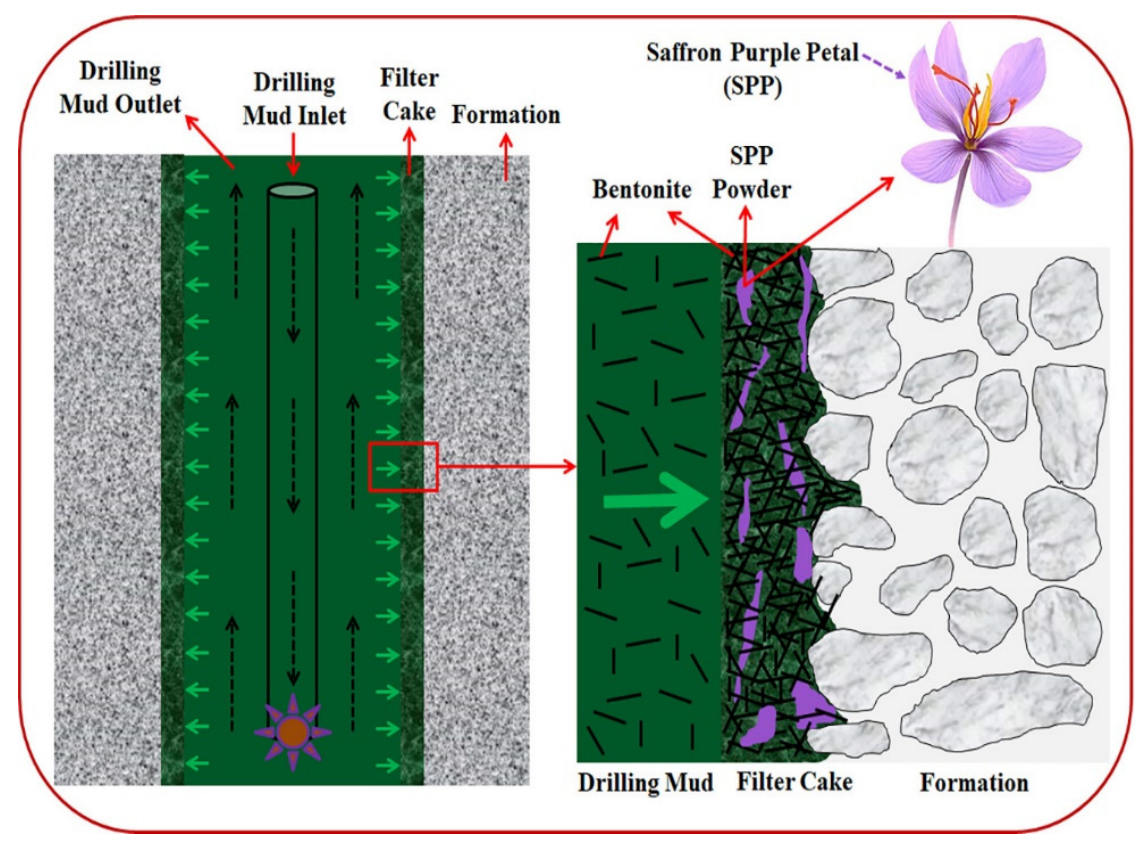

Figure 4. Schematic illustration of mud cake thickness and filter loss using saffron purple petals compared to bentonite based mud [56].

Recent studies have shown the impact of various waste-derived additives for efficient rheological properties in drilling fluids [57]. For example, Joshi et al. reported on the use of tamarind kernel powder as an alternative additive in drilling fluids. The study outlined the impact of using tamarind kernel powder on the mud density. Mud density is one of the significant properties of drilling fluids, and helps provide and regulate wellbore stability and control formation pressure. In the study, it was stated that the density of the mud sample increases with the addition of tamarind seed powder and the combination of bentonite. Increasing the concentration of tamarind seed powder resulted in a thicker mud sample and an increase in mud density. The mud density of the samples was observed to be in the range of $8.22-8.97 \mathrm{ppg}$, which has been considered to be a suitable range for use as an additive in the formulation of drilling fluids [58].

Moreover, Murtaza et al. demonstrated the use of environmentally-friendly okra as a viable alternative additive in drilling fluids. The performance of okra as an additive was evaluated with the absence and presence of clay in drilling fluids. Comparatively, the incorporation of okra in clay-based drilling fluids presented a greater improvement in the rheological properties compared to that in clay-free drilling fluids. In clay-based drilling fluids, the addition of 2 and $3 \mathrm{~g}$ of okra resulted in an increase in plastic viscosity (PV) of more than $100 \%$, compared to the addition of $2 \mathrm{~g}$ of starch, which only yielded a $45.7 \%$ increment. Increasing the concentration of okra also led to an increase in the yield point of drilling fluids. However, was observed that starch is more efficient in improving the yield point than okra. Fluid loss was evaluated at different concentrations and observed to be reduced at different proportions for each concentration [59]. In addition, the filter cake thickness was reduced with the addition of okra, with further reductions evident at higher concentrations, as shown in Figure 5a-d. 

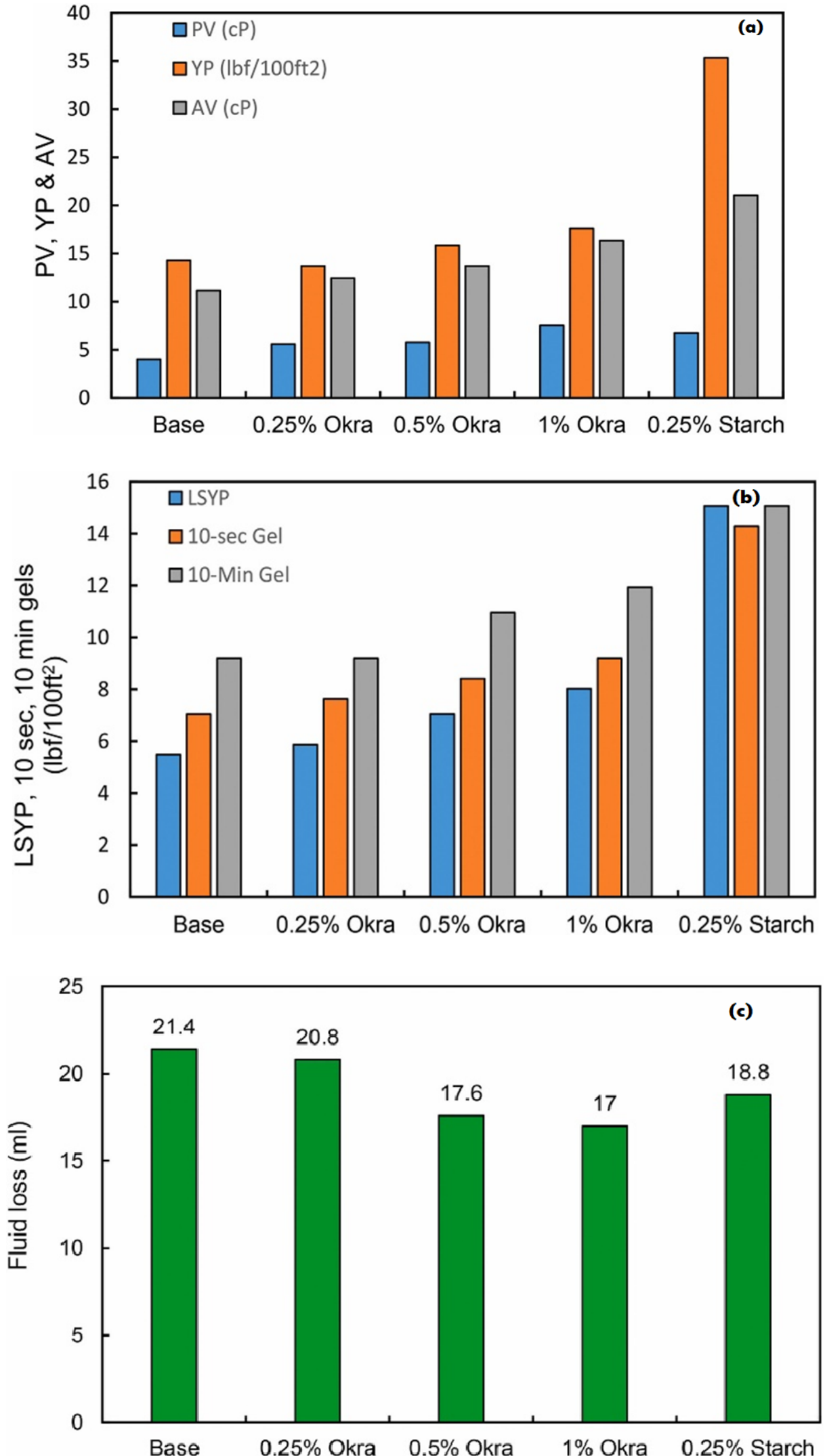

Figure 5. Cont. 


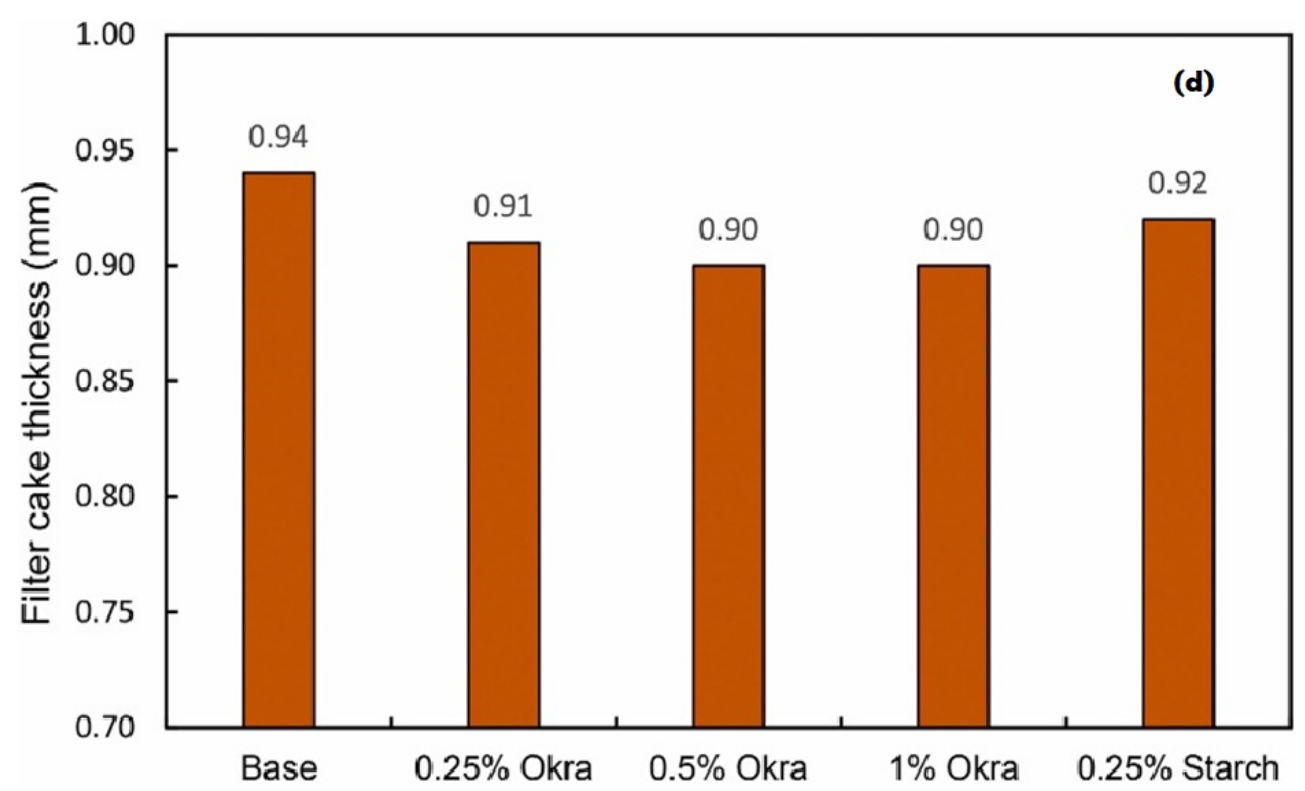

Figure 5. Graphical representation of okra powder as an eco-friendly additive in water-based drilling fluids. Increase in plastic viscosity, yield point, apparent viscosity, and gel strength $(\mathbf{a}, \mathbf{b})$, and decrease in fluid loss and mud cake thickness (c,d), using various additive concentrations (\%) of okra powder versus starch [59].

Similarly, Ghaderi et al. proposed sustainable saffron purple petals (SPP) as an ecofriendly alternative for additives in drilling fluids. The addition of SPP powder in drilling mud resulted in an effective increase in PV values. As the concentration of SPP powder increases, the PV value also increases. Additionally, the introduction of SPP powder to drilling mud also dramatically enhances the yield point compared to that of base mud. The incorporation of SPP powder into drilling mud demonstrated excellent filtrate loss, whereby the filtrate volume was reduced gradually with increasing concentration of SPP powder. The addition of SPP powder in the drilling mud also resulted in the reduction of mud cake thickness compared to that in base mud [56,60].

The above-mentioned studies have demonstrated the effectiveness of food waste in drilling fluid additives as a substitute for the environmentally hazardous materials currently in use within the industry [61]. In this regard, there is a need to promote the "waste to wealth" concept by studying the potential of using unused waste derivatives as additives in drilling fluids, and to address the issue by exploring the additives' rheological properties, which ensure it is viable and cost effective [62]. Table 1 displays the role of varying waste materials used as additives for the improved rheological properties of water-based drilling fluids.

\subsection{Bentonite in Drilling Fluids}

Bentonite is a clay material that is naturally composed of sodium montmorillonite and minor quantities of minerals. It is used in a variety of applications due to its absorption and adsorption capabilities [58]. For instance, it has been used as a health remedy because it contains iron, magnesium, and calcium. In clay form, these elements are beneficial because they absorb and remove toxins from the body [80].

In the presence of water, bentonite hydrates and swells to form a thixotropic gel, i.e., a mud cake, thus protecting the well formation from invasion, which causes the loss of fluids to permeable formations. However, mud cakes formed by bentonite have been found to be highly detrimental to the productivity of drilled wells. This is due to the inefficient removal of protective mud cakes that is undertaken to restore performance of wells [81]. According to Li et al., he difficulty to remove mud cake greatly increases in deeper reservoirs. [82]. 
Table 1. Summary of rheological properties of waste-derived materials in drilling fluids.

\begin{tabular}{|c|c|c|c|c|c|c|c|}
\hline Types of Wastes Materials & Process Parameters & $\begin{array}{c}\text { Range of } \\
\text { Particle Size }\end{array}$ & $\begin{array}{c}\text { Amount of } \\
\text { Waste Used (g) }\end{array}$ & $\begin{array}{l}\text { Yield Point } \\
\left(\mathrm{lb} / 100 \mathrm{ft}^{2}\right)\end{array}$ & $\begin{array}{c}\text { Plastic } \\
\text { Viscosity (cP) }\end{array}$ & $\begin{array}{l}\text { Filtrate Loss } \\
\text { (\% Reduction) }\end{array}$ & References \\
\hline Basil Seed Powder (BSP) & $90-150{ }^{\circ} \mathrm{C}$ & $5-10 \mu \mathrm{m}$ & 1 & 5-45 Pa & 5-28 mPa.s & $10.2-67.9 \%$ & [63] \\
\hline $\begin{array}{l}\text { Carboxymethyl cellulose } \\
\text { carton waste (CMC) }\end{array}$ & - & - & $1-5 \mathrm{~g}$ & - & - & $0.4-10 \%$ & [64] \\
\hline $\begin{array}{l}\text { Wild Jujube Pit } \\
\text { Powder (WJPP) }\end{array}$ & 6.9 MPa & $54,75,100 \mu \mathrm{m}$ & - & $1.5-2.5 \mathrm{~Pa}$ & 3-4 mPa.s & $30-47.5 \%$ & [65] \\
\hline Banana Peel Powder (BPP) & - & - & $6-18 \mathrm{~g}$ & $10-16$ & $6-12$ & $39-54 \%$ & [66] \\
\hline $\begin{array}{l}\text { Black Sunflower Seeds } \\
\text { Shell Powder }\end{array}$ & $250^{\circ} \mathrm{F}, 500 \mathrm{psi}$ & $52-400 \mu \mathrm{m}$ & $3.5-24.5 \mathrm{~g}$ & $26-47$ & $7-13$ & $0.3-25 \%$ & [51] \\
\hline $\begin{array}{l}\text { Brachystegia eurycoma } \\
\text { rice husk }\end{array}$ & - & - & 20 & - & - & $35.62 \%$ & [67] \\
\hline $\begin{array}{l}\text { Detarium microcarpum } \\
\text { rice husk }\end{array}$ & - & - & 15 & - & - & $44.44 \%$ & [67] \\
\hline $\begin{array}{l}\text { Fibrous Food Waste } \\
\text { Material (FFWM) }\end{array}$ & $100 \mathrm{psi}$ & $2 \%$ & - & 13 & 8 & $7.0 \mathrm{cc} / 30 \mathrm{~min}$ & [15] \\
\hline $\begin{array}{l}\text { Green Olive Pits' } \\
\text { Powder (GOPP) }\end{array}$ & - & $1.5 \%$ & 9 & 26 & 7 & $11.5 \mathrm{cc} / 30 \mathrm{~min}$ & [68] \\
\hline Henna leaf extract & $78^{\circ} \mathrm{F}, 300^{\circ} \mathrm{F}, 100 \mathrm{psi}$ & - & $10-40$ & $33-52$ & $23-45$ & $29.9-32 \%$ & [17] \\
\hline Hibiscus leaf extract & $78^{\circ} \mathrm{F}, 300^{\circ} \mathrm{F}, 100 \mathrm{psi}$ & - & $10-40$ & $73-148$ & $41-75$ & $31.0-35.1 \%$ & [17] \\
\hline $\begin{array}{l}\text { Palm Tree Leaves } \\
\text { Powder (PTLP) }\end{array}$ & $55^{\circ} \mathrm{C}$ & $3 \%$ & 22 & 5 & 9 & $8.9 \mathrm{cc} / 30 \mathrm{~min}$ & [69] \\
\hline Potato Peels Powder (PPP) & $73^{\circ} \mathrm{F}$ & $4 \%$ & 6 & 6 & 10 & $8.75 \mathrm{cc} / 30 \mathrm{~min}$ & [70] \\
\hline Saffron Purple Petals (SPP) & $100 \mathrm{psi}$ & - & $50 \mathrm{~g}$ & 6.04-10.67 Pa & $\begin{array}{c}0.016-0.039 \\
\text { Pa.s }\end{array}$ & $23-45 \%$ & [56] \\
\hline Durian rind & - & $44-2000 \mu \mathrm{m}$ & $5-10 \mathrm{ppb}$ & $2-75$ & $10-80$ & $17-60 \%$ & [71] \\
\hline $\begin{array}{l}\text { Mandarin peels } \\
\text { powder (MPP) }\end{array}$ & - & $1-4 \%$ & - & $14-57$ & $14-63$ & $44.0-68.0 \%$ & [49] \\
\hline Date Seed Powder & $100 \mathrm{psi}$ & $300 \mu \mathrm{m}$ & $0.25-2 \mathrm{ppb}$ & 4 & 9 & $8-20 \%$ & [72] \\
\hline Pistachio Shell Powder (PSP) & $104.44^{\circ} \mathrm{C}, 3.45 \mathrm{MPa}$ & $75-150 \mu \mathrm{m}$ & $5-9 \mathrm{~g}$ & $12.2-13.5$ & $19.8-24$ & $15.3-44 \%$ & [73] \\
\hline Soybean Peel Powder (SB) & $100 \mathrm{psi}$ & - & $5 \mathrm{ppb}$ & 23 & 4 & $60 \%$ & [74] \\
\hline Grass & - & $35-300 \mu \mathrm{m}$ & $0.25-1 \mathrm{ppb}$ & $3.5-5$ & $8-9$ & $11.0-14.6 \%$ & [75] \\
\hline Corn Starch & $170-200^{\circ} \mathrm{F}$ & $<125 \mu \mathrm{m}$ & 6 & - & $2.67-5$ & $31 \%$ & [76] \\
\hline Rice husk & - & $125 \mu \mathrm{m}$ & $5-20$ & $9.56 \mathrm{~Pa}$ & 0.008 Pa.s & $16.0-42.5 \%$ & [77] \\
\hline Agarwood & - & $45 \mu \mathrm{m}, 90 \mu \mathrm{m}$ & - & 22 & 11.9 & 14.0 & [78] \\
\hline Sawdust & $70^{\circ} \mathrm{C}$ & $1 \mathrm{~mm}$ & - & - & - & $8.6 \%$ & [79] \\
\hline Walnut shells & - & $2-6 \mathrm{~mm}$ & $20-60$ & 110-180 & $55-80$ & $11.0-14.5 \%$ & [80] \\
\hline
\end{tabular}

Most importantly, because bentonite clay contains montmorillonite, a crystalline structure that forms the clay, bentonite precipitates when water is added [83]. This is beneficial in drilling fluids, in which the ability to precipitate significantly assists in reservoir formation and protection from the invasion of drilling fluids into the reservoir when exposed to water [84]. The impact of Na-bentonite as a weighing agent on mud density is compared with ilmenite and barite in Figure 6.

Magzoub et al. have studied bentonite compounds comprising different primary elements, such as calcium (Ca), potassium (K), and sodium ( $\mathrm{Na}$ ), and found that sodium bentonite is commonly utilized in drilling fluids. In contrast, calcium is rarely used due to its unsatisfactory rheological properties. However, this study used sodium to activate the calcium bentonite to improve its performance [86].

Karagüzel et al. have found that sodium and calcium bentonites in combination with soda and $\mathrm{MgO}$ additives show enhanced swelling properties, lower filtrate loss, and increased viscosity at favorable concentrations. An important fact to note is that although sodium and calcium bentonites were used as mud viscosifiers and fluid loss reducers, they did not qualify as good drilling fluids. This finding highlights the importance of choosing suitable additives that can effectively enhance the properties of a drilling fluid [87]. 


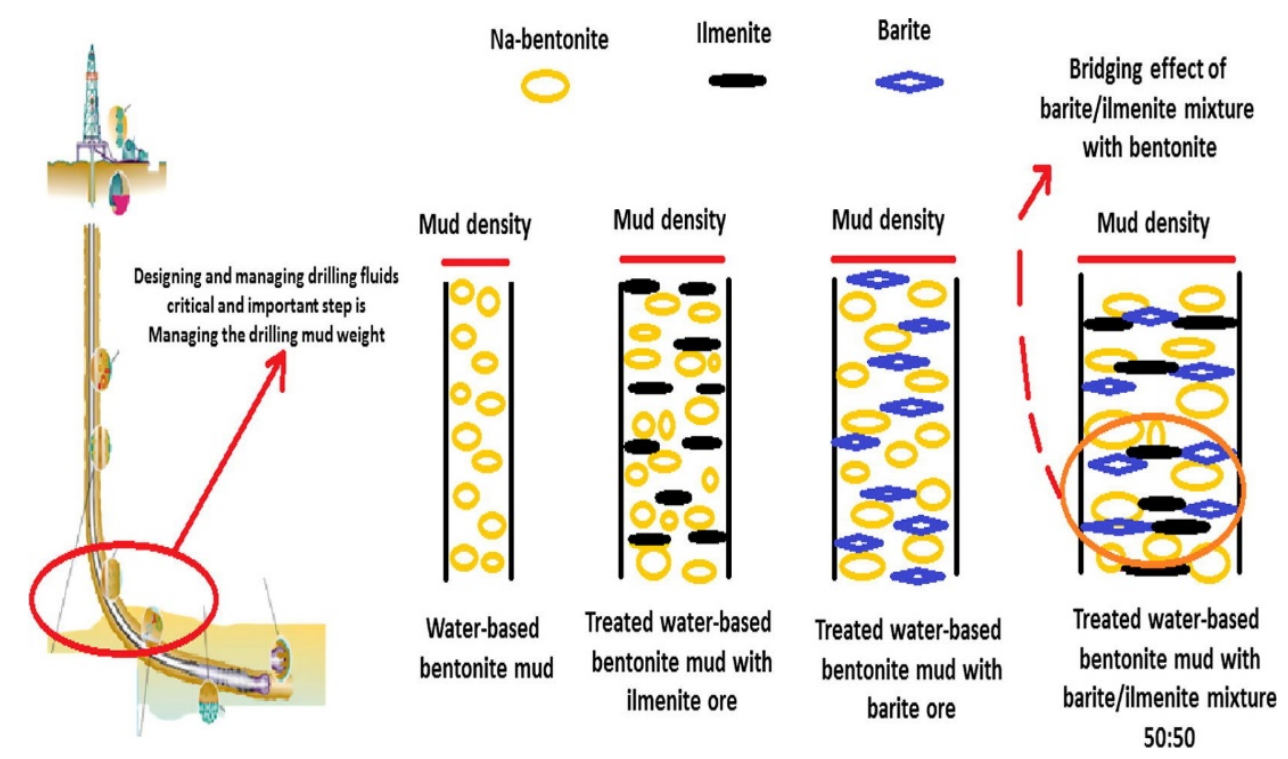

Figure 6. Schematic diagram of the mud weight bridging effect using bentonite, ilmenite, and barite [85].

The disadvantages of bentonite have been studied, leading to the formulation of nanomaterial-based drilling fluids, and resulting in significant improvements in wellbore cleaning properties while successfully maintaining optimum viscosity and density [88] Compared to conventional bentonite, the breakthrough study by Xie et al. have introduced the successful use of nanofluids which reduced mud filtrate and enhanced thermal conductivity as well as rheological properties of the WBDF [89].

\section{Effects of Nanomaterials in Drilling Fluids}

Nanomaterials are manufactured substances that have a size ranging from 1 to 100 nanometres $(\mathrm{nm})$, and therefore are utilized in extremely small dimensions [90,91]. Nanomaterials are widely applied in various fields, such as pharmaceutical, automotive, and electronics industries and, most notably, in several areas within the chemical industry. An example of these is the drilling industry [92,93].

To facilitate the drilling of a borehole, drilling fluids imparts a vital factor for a successful drilling operation; that is, the fluids help remove the drill cuttings and fragments from the drilling area and the wellbore.

Nanomaterials have an extremely high surface area to volume ratio due to their nano-sized particles. Therefore, WBDF containing nanomaterial active agents possesses improved physical and chemical sensitivity, which enhances its performance efficiency compared to that of OBDF [94]. In addition to exhibiting advantages compared to OBDF, the improved nano-based WBDF is also cheaper and more environmentally friendly. For example, graphitic nanomaterials are excellent binding agents and have successfully been used to develop a compact, impermeable, and thinner mud cake [95]. This enables nano-pores to be physically plugged together, thereby reducing water losses during shale formations. Consequently, the use of the graphene family enhances wellbore stability [96].

Furthermore, nanomaterials have also been used as lubricants to reduce friction between the wellbore and drill string, which consequently reduces the likelihood of a stuck pipe. Figure 7 demonstrates the increase in surface area of nanoparticles compared to macroparticles of the same volume. 


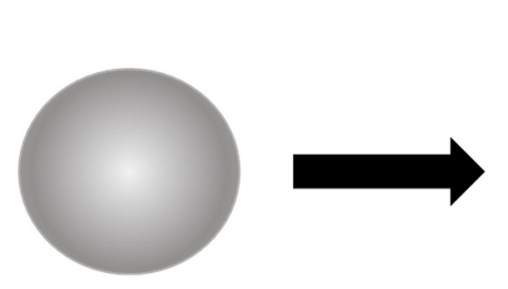

Macroparticle

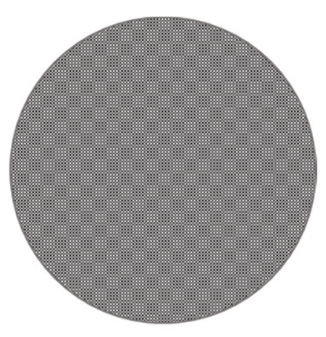

Nanoparticle

Figure 7. Comparison of macroparticle and nanoparticle surface area to volume ratios.

The pioneering works on the significant usage of nanomaterials in drilling fluids were undertaken by Abdo et al. [97]. In enhanced oil recovery and drilling operations, Amanullah et al. reported the promising use of nanomaterials in smart fluid development due to their enhanced physio-mechanical, chemical, electrical and thermal properties [98]. At a very small concentration of nano-silica $\left(\mathrm{SiO}_{2}\right)$, the rheological, hydraulic, and filtration properties of WBDF are effectively improved [99]. In a recent study, Karakosta et al. testified the improved drilling efficiency in the HTHP environment when metal oxide nanomaterials are used [19]. The addition of nanomaterials as additives reduced the amount of filtrate entering the reservoir, thus preventing potential damage [100]. Gautam et al. showed the positive impact of nanoparticle usage on controlling filtrate loss and mud cake thickness [101]. In summary, the use of drilling fluids improves drilling efficiency, reduces drilling costs, and is less damaging to the environment [102].

For example, Kasiralvalad et al. found that adding traces of nanomaterials to the drilling fluid, thereby making it a nanofluid, played an essential role in enhancing the mud cake quality, and reduced the sticking of the pipe to the reservoir, promoted good borehole stability and reservoir protection, and increased recovery of both oil and gas products. This was possible due to the modifications to the fluid caused by the nanoparticles, which aided in its superior performance [103].

Another reflection of this finding was provided by the study of Li et al., in which the authors established that nanomaterials helped to improve the mud cake quality and reduced loss circulation. In addition to these qualities, they also found that when nanomaterials were used as viscosifiers, emulsifiers, and lubricants, they improved the qualities of borehole cleaning, borehole stability, and reservoir protection, and enhanced oil and gas recovery [104].

Salih et al. emphasized the concentration of nanomaterials, and found that the rheological and filtration properties of the drilling fluid were superior at a low concentration compared to the inferior performance achieved at a higher concentration. Other researchers analyzed noteworthy parameters related to nanomaterial usage [105]. This research highlights the key factors to be considered to ensure a good performance of drilling fluids, as displayed in Figure 8.

In addition to waste-derived materials, recent studies have presented nanomaterials as promising alternative for use as additives in drilling fluids. As an example, Kamali et al. assessed the effects of $\mathrm{Fe}_{3} \mathrm{O}_{4}$-carboxymethyl cellulose (CMC) nanocomposite as a fluid loss control additive in drilling fluids. In this study, the effect on rheological properties of drilling mud with and without salt was studied. The study observed that the utilization of the nanocomposite enhances the fluid viscosity of the drilling mud under both conditions. Based on the study results, in general, the yield point of the drilling fluid is further increased with increasing concentration of the nanocomposite. It was observed that the integration of the nanocomposite into the drilling fluid allows for the production of a thinner filter cake in comparison to the CMC mud system [107]. In addition, a reduction in filtrate loss was recorded with an increasing concentration of the nanocomposite, as seen in Figure 9. 


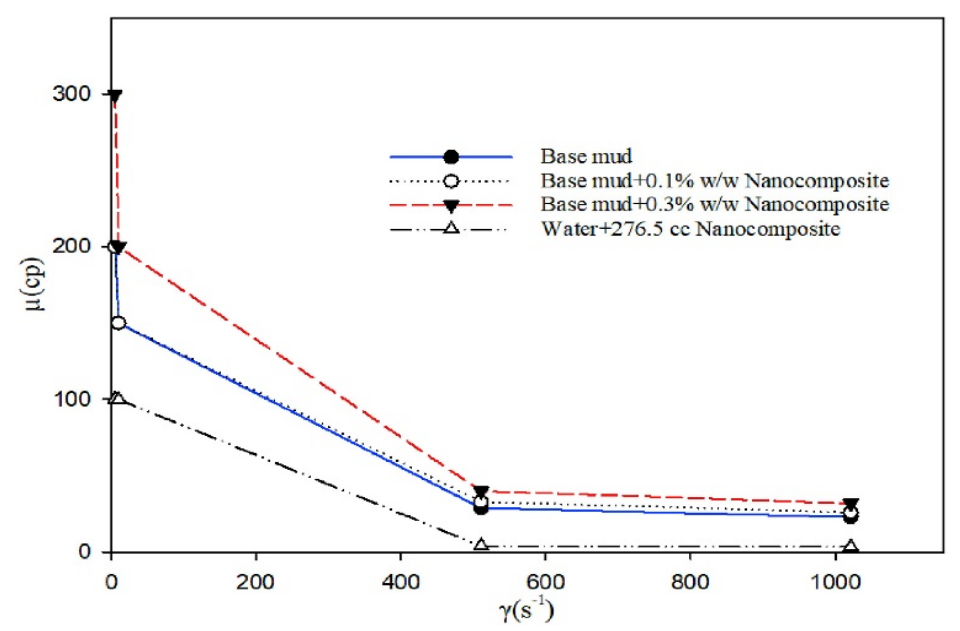

Figure 8. Viscosity versus shear rate using different concentrations of nanocomposite. Higher nanocomposite concentration results in a significant increase in viscosity [106].

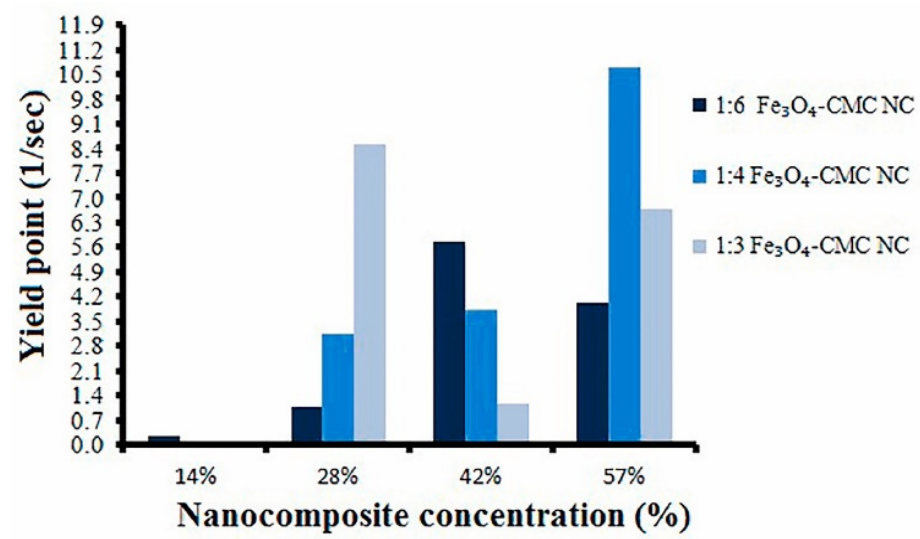

Figure 9. Yield point verses nanocomposite concentrations. Nanocomposite with the ratio 1:4 increased the yield point to a maximum of 50\% compared to other ratios [107].

Saboori et al. highlighted the importance of adding the appropriate concentration of additives to the drilling fluid for improved properties. They investigated the addition of varying concentrations of copper oxide $(\mathrm{CuO})$, also called polyacrylamide nanocomposite, to a water-based drilling fluid. They found that increased concentration significantly minimized fluid loss and filter cake thickness in comparison to the absence of nanocomposites. They also observed higher viscosity, higher thermal conductivity, and a favorable filter cake porosity [108].

Another important distinction was made by comparing drilling fluid performance between salty and non-salty water. It was found that both types displayed the best performance under certain conditions, and that a specific salt concentration may result in the best performance for both salty and non-salty water. This study again showed that additives play a vital role in the performance of a drilling fluid [109]. Figure 10 presents the effects of CMC on the reduction in filtrate loss compared to nanocomposites using various concentrations.

A compelling recent study carried out by Lekomtsev et al. utilized tools including an Extreme Learning Machine (ELM) and Particle Swarm Optimization-Least Square Support Vector (PSO-LSSVM) to investigate the effect of various nanoparticles on the filtration of a volume of drilling fluids. This research showed a decrease in the amount of filtration volume with the increase in the weight percentage of the nanoparticles. Among the parameters evaluated, the study indicated that nanoparticle concentration had the greatest impact on the filtration volume and mud cake thickness of drilling fluids $[110,111]$. 

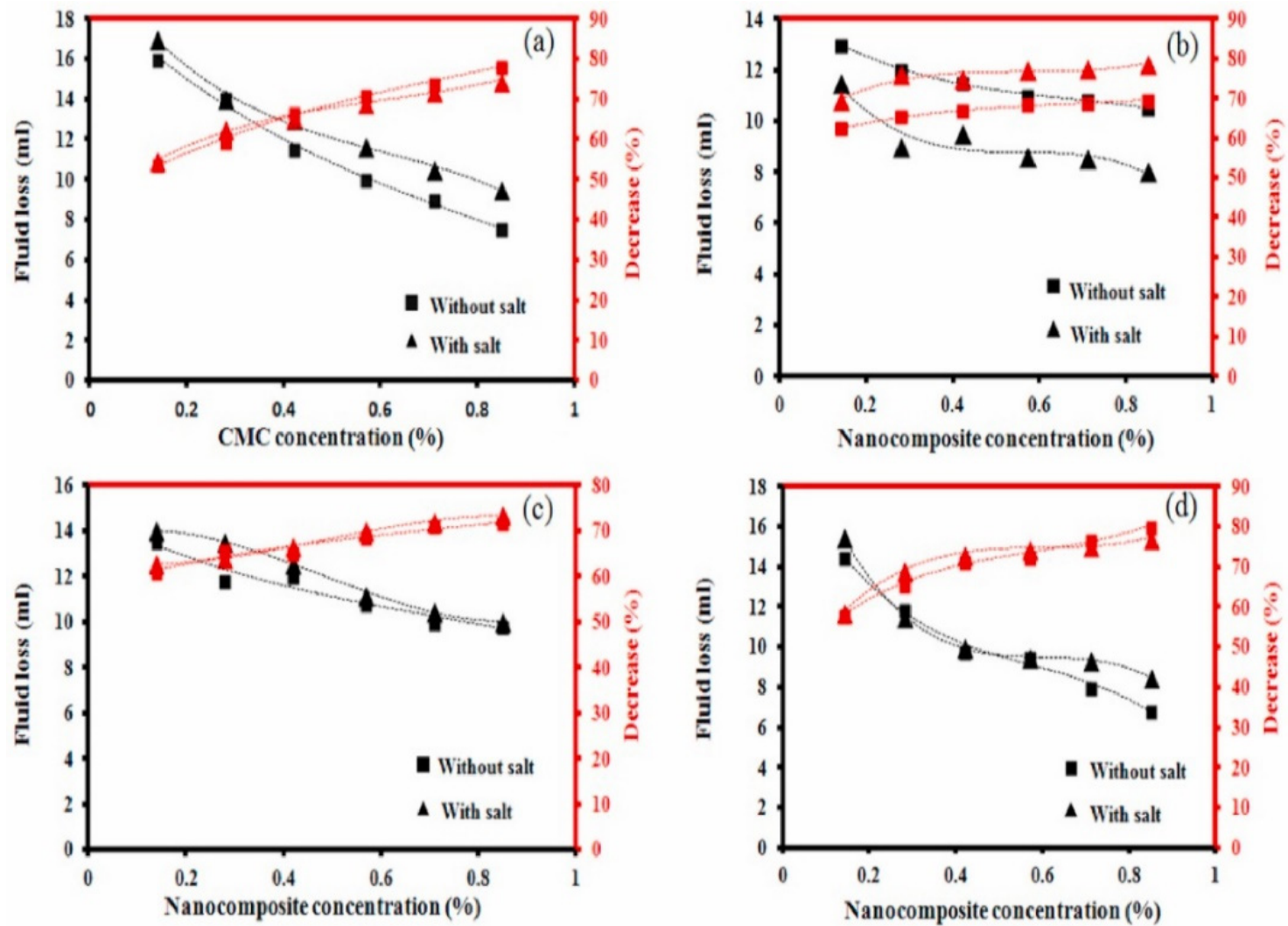

Figure 10. Fluid loss acquired using (a) CMC, (b) 1:6, (c) 1:4, and (d) 1:3 $\mathrm{Fe}_{3} \mathrm{O}_{4}$-CMC nanocomposite ratios. Higher ratios of nanocomposite show improved fluid loss volume compared to CMC [107].

Al-Zubaidi et al. studied nano-Iraqi clay and other nanomaterials, such as graphene and magnesium oxide (MgO), in various concentrations and separately combined with commercial nano-bentonite to observe the performance of the fluid. The addition of $\mathrm{MgO}$ with nanomaterials resulted in an improved filter loss and yield point. This demonstrates that a wide range of additives with appropriate concentrations can improve the performance of drilling fluids [112].

Graphenaceous materials have been extensively used in drilling fluids because they promote and enhance the rheological properties of these fluids. Kosynkin et al. found that the use of a graphene oxide additive in water-based drilling fluids improved its filtrate loss properties, significantly lowering the filter cake thickness and fluid loss, and screening enhanced shear thinning and thermal stability. It was also observed that graphene in both flake and powdered form was a contributing factor to the improved performance. This study indicates that the presence of an additive influences the properties of a drilling fluid, and shows how the form of the additive can contribute to value-added properties [113].

Sadeghalvaad and Sabbaghi studied a $\mathrm{TiO}_{2}$ / polyacrylamide nanocomposite as an additive in water-based drilling fluids, and found a significant reduction in fluid loss and mud cake thickness with its use, as observed in Figure 11 [114].

Patel et al. observed that conventional water drilling muds exposed to water sensitive shale cause the shale to absorb water from the mud, resulting in problems during operation. Therefore, the water-based muds must contain additives to effectively inhibit the shale. Salt compounds were used to inhibit the shale. However, the high concentrations of the salt compounds affected the surrounding ecosystems. The concentration was altered, and the shale was successfully inhibited [115]. This study demonstrates the importance of the optimal concentrations of additives in drilling fluids to achieve the superior performance of the drilling fluid without causing side effects [116]. 

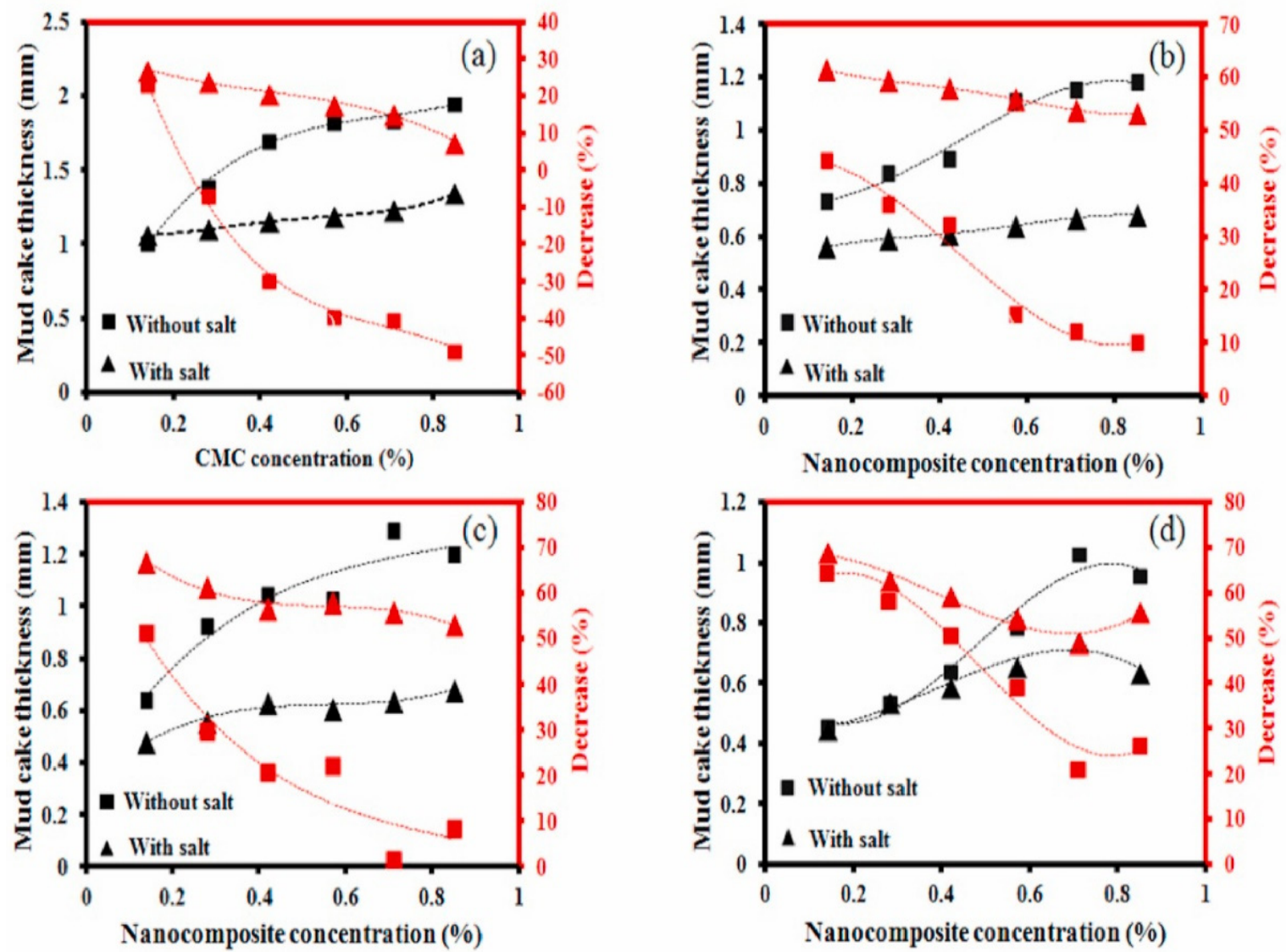

Figure 11. Mud cake thickness attained using (a) CMC, (b) 1:6, (c) 1:4, and (d) 1:3 $\mathrm{Fe}_{3} \mathrm{O}_{4}$-CMC nanocomposite ratios. The mud cake thickness was reduced by $44.27 \%, 51.14 \%$, and $64.88 \%$, respectively, as compared to CMC, which showed an increase in thickness of up to $48 \%$ [107].

Similarly, Qu et al. investigated polyoxyalkyleneamine (POAM) as a potential additive and found that POAM improved the shale inhibition capabilities in water-based drilling fluids [117]. As an added benefit, POAM is water soluble, has good compatibility with other additives in the drilling fluid, and is nontoxic. Subsequently, nanomaterials have been explored as potential additives to be used in drilling fluids [118].

In the drilling industry, many researchers have studied nanomaterials and found a wide range of chemicals that can improve the properties of drilling fluids. The clear advantage of using nanomaterials is that the amount required is very small [119]. Hence, the use of nanomaterials can conserve resources. The drilling industry spends millions of dollars to address situations of wellbore instability [120]. The use of nanomaterials as additives to drilling fluids should be economically sound so that resources can be conserved. For instance, nanomaterials that are used for filtration reduction, such as viscosifiers, emulsions, and clays, can decrease the rate of water penetration into shale because these nanomaterials are small enough to seal the shale, thereby strengthening the wellbore [121]. Aramendiz et al. found that $\mathrm{SiO}_{2}$ nanoparticles added to water-based drilling fluids enhance inhibition, and filtrate loss and rheological properties. The added benefit is that the preparation of $\mathrm{SiO}_{2}$ nanoparticles has a low cost due to their common methods of preparation [122].

Similarly, Taraghikhah et al. found that the optimal concentration of $\mathrm{SiO}_{2}$ nanoparticles is below $1 \% w / v$ in shale inhibition, thus constituting a very small, and hence economical, concentration [123].

Gbadamosi et al. investigated $\mathrm{SiO}_{2}$ nanoparticles as an additive in water-based drilling fluids. They found that $\mathrm{SiO}_{2}$ nanoparticles increased the viscosity of the fluid, thereby allowing it to more efficiently carry drill cuttings from the wellbore. This ensures the 
wellbore is clean and, therefore, does not pose challenges when the drill needs to be removed or maintenance work is required [124].

Al-Yasiri et al. also investigated the use of $\mathrm{SiO}_{2}$ nanoparticles with xanthan gum as a base in water-based drilling fluids, and found an increased yield point, superior hole cleaning ability, reduced filtrate loss, and more efficient lubrication of the drill bit during operation compared to drilling fluids without $\mathrm{SiO}_{2}$ [125].

Bayat et al. studied four nanoparticles types, namely, aluminum oxide $\left(\mathrm{Al}_{2} \mathrm{O}_{3}\right)$, titanium dioxide $\left(\mathrm{TiO}_{2}\right), \mathrm{SiO}_{2}$, and $\mathrm{CuO}$ in bentonite, and their effects on water based drilling fluids. They found that the combined additives improved overall rheological properties and gel strength at low concentrations in comparison to the base fluid without nanoparticles [52]. This shows that additives efficiently increase rheology using a small concentration and thus conserve resources in the drilling process.

Another recent study by Medhi et al. evaluated the impact of zinc oxide $(\mathrm{ZnO})$ nanoparticles on the rheological properties of non-damaging drilling fluid (NDDF). In comparison to base NDDF, NDDF incorporated with $\mathrm{ZnO}$ nanoparticles exhibited higher shear stress and viscosity. The addition of $\mathrm{ZnO}$ nanoparticles to NDDF helped overcome the issue of NDDF degradation through stabilization of viscosity at higher temperatures. Temperature sweep test measurements indicated a good operational temperature range of base NDDF was between 70 and $80^{\circ} \mathrm{C}$. NDDF containing $\mathrm{ZnO}$ nanoparticles exhibited improvement in fluid loss control. However, it was observed that an increase in pressure resulted in a decrease in fluid loss [126]. Table 2 summarizes numerous studies on modifications of rheological properties and reduction in filtrate loss by adding nanomaterials as additives.

Table 2. Literature studies on the effects of nanomaterials as fluid loss agents in drilling fluids.

\begin{tabular}{|c|c|c|c|c|}
\hline $\begin{array}{c}\text { Types of } \\
\text { Nanomaterials }\end{array}$ & $\begin{array}{c}\text { Modified Rheological } \\
\text { Properties }\end{array}$ & $\begin{array}{c}\text { Experimental } \\
\text { Parameters }\end{array}$ & Conclusions & References \\
\hline $\begin{array}{l}\text { Carbon nano-tubes } \\
\text { (CNT) }\end{array}$ & $\begin{array}{ll}\text { - } & \text { Filtration loss } \\
\text { (API and HTHP) } \\
\text { - } \quad \text { Shale inhibition }\end{array}$ & 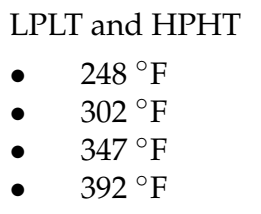 & $\begin{array}{l}\text { Addition of } 0.8 \% \text { CNT in } \\
\text { WBDF reduced significant } \\
\text { filtration loss in HTHP } \\
\text { conditions. }\end{array}$ & [127] \\
\hline Ferric oxide $\left(\mathrm{Fe}_{2} \mathrm{O}_{3}\right)$ & $\begin{array}{ll}- & \text { Filtration loss } \\
& \text { (API and HTHP) }\end{array}$ & LPLT and HPHT & $\begin{array}{l}\text { Addition of } \mathrm{Fe}_{2} \mathrm{O}_{3} \text { in } \\
\text { nanoparticles increased fluid } \\
\text { loss at LTLP. }\end{array}$ & [128] \\
\hline Graphene & $\begin{array}{ll}\text { - } & \text { Filtration loss (API) } \\
\text { - } & \text { Shale inhibition }\end{array}$ & $\begin{array}{l}\text { LPHT } \\
\text { • } \quad 120^{\circ} \mathrm{F} \\
\text { - } \quad 351^{\circ} \mathrm{F}\end{array}$ & $\begin{array}{l}\text { Results showed } 30 \% \text { API } \\
\text { filtration loss when } 1-5 \mathrm{wt} \% \text { of } \\
\text { graphene were added to } \\
\text { nanoparticles in } 10 \mathrm{ppg} \text { WBDF. }\end{array}$ & [129] \\
\hline $\begin{array}{ll}\text { - } & \text { MWCNT } \\
\text { - } & \text { Gold } \\
& \text { nanoparticles }\end{array}$ & $\begin{array}{ll}\text { - } & \text { Filtration loss (API) } \\
\text { - } & \text { Mud cake thickness }\end{array}$ & LPLT & $\begin{array}{l}\text { Au nanoparticles-MWCNT at } \\
0.005 \% \text { w/v exhibit reduction in } \\
\text { filtration loss by } 6 \% \text {. }\end{array}$ & [130] \\
\hline $\begin{array}{ll}\text { - } & \text { MWCNT } \\
\text { - } & \text { Graphene oxide }\end{array}$ & $\begin{array}{ll}\text { - } & \text { Filtration loss } \\
\text { - } & \text { Mud cake thickness }\end{array}$ & $\begin{array}{l}\text { LPLT } \\
\bullet \quad \sim 100 \text { psi }\end{array}$ & $\begin{array}{l}\text { MWCNT and graphene oxide } \\
\text { at ratio } 1: 1 \text { of } 0.2 \mathrm{~g} \text { each, } \\
\text { reduces fluid loss and mud } \\
\text { cake thickness. }\end{array}$ & [131] \\
\hline Polystyrene & $\begin{array}{ll}\text { - } & \text { Filtration loss } \\
\text { (API and HTHP) } \\
\text { - } & \text { Mud cake thickness }\end{array}$ & $\begin{array}{l}\text { LPLT and HPHT } \\
\text { - } \quad 24-150{ }^{\circ} \mathrm{C} \\
\text { - } \quad 100-500 \mathrm{psi}\end{array}$ & $\begin{array}{l}\text { Reduction of } 50.7 \% \text { and } 61.1 \% \\
\text { of filtration loss for LPLT and } \\
\text { HPHT conditions, respectively. } \\
\text { Low permeable and thinner } \\
\text { mud cake thickness is also } \\
\text { observed through addition of } \\
\text { nano-polystyrene. }\end{array}$ & [132] \\
\hline
\end{tabular}


Table 2. Cont.

\begin{tabular}{|c|c|c|c|c|}
\hline $\begin{array}{l}\text { - } \quad \text { Polystyrene } \\
\text { - } \quad \text { Clay }\end{array}$ & $\begin{array}{ll}\text { - } & \text { Filtration loss (API) } \\
\text { - } & \text { Yield point } \\
& \text { Gel Strength }\end{array}$ & $250^{\circ} \mathrm{F}$ & $\begin{array}{l}\text { Nanocomposite achieved a } \\
\text { reduced API filtration loss by } \\
22 \% \text { in WBDF and showed } \\
\text { excellent thermal stability at } \\
\text { high temperature, } 250^{\circ} \mathrm{F} \text {. }\end{array}$ & [109] \\
\hline Sepiolite & $\begin{array}{ll}\text { - } & \text { Filtration loss } \\
\text { - } & \text { Mud cake thickness }\end{array}$ & $\begin{array}{l}\text { HPHT } \\
\text { • } \quad 77-365^{\circ} \mathrm{F} \\
\bullet \quad 100-16,000 \mathrm{psi}\end{array}$ & $\begin{array}{l}4.0 \mathrm{wt} \% \text { of nano-sepiolite with } \\
30-90 \mathrm{~nm} \text { diameter showed } \\
\text { reduced filtration loss under } \\
\text { HPHT conditions. }\end{array}$ & [133] \\
\hline GO & $\begin{array}{ll}\text { - } & \text { Filtration loss } \\
\text { - } & \text { Mud cake thickness }\end{array}$ & HPHT & $\begin{array}{l}\text { Graphene oxide nanosheets } \\
\text { using }>0.5 \mathrm{wt} \% \text { improved } \\
\text { stability by plugging and } \\
\text { sealing of micropores. } \\
\text { Reduction in filtration loss by } \\
\text { up to } 50 \% \text { by adding } 0.8 \mathrm{wt} \% \\
\text { of graphene oxide } \\
\text { was observed. }\end{array}$ & [134] \\
\hline $\begin{array}{l}\text { Polymer-graphene } \\
\text { oxide }\end{array}$ & - $\quad$ Filtration loss & $240^{\circ} \mathrm{C}$ & $\begin{array}{l}\text { Highly efficient filtration loss } \\
\text { properties as compared to } \\
\text { bentonite-based mud. }\end{array}$ & [135] \\
\hline $\mathrm{SiO}_{2}$ & $\begin{array}{ll}\text { - } & \text { Filtration loss } \\
\text { - } & \text { Mud cake thickness }\end{array}$ & $\begin{array}{l}\text { LPLT and HPHT } \\
\text { • } \quad 199^{\circ} \mathrm{F} \\
\text { • } \quad 1000 \mathrm{psi}\end{array}$ & $\begin{array}{l}0.7 \mathrm{wt} \% \text { of } \mathrm{SiO}_{2} \text { reduces } \\
\text { filtration losses when } \\
\text { concentration of } \mathrm{SiO}_{2} \text { is } \\
\text { increased. In addition, the } \\
\text { lowest mud cake thickness } \\
(1 \mathrm{~mm}) \text { was also obtained. }\end{array}$ & [105] \\
\hline $\begin{array}{l}\text { Synthetic based } \\
\text { Acrylamide-styrene } \\
\text { Copolymer(SBASC) }\end{array}$ & $\begin{array}{ll}\text { - } & \text { Plastic viscosity } \\
\text { - } & \text { Yield point } \\
\text { - } & \text { Gel strength } \\
\text { - } & \text { Filtration loss }\end{array}$ & $250^{\circ} \mathrm{F}$ & $\begin{array}{l}\text { SBASC achieved reduction in } \\
\text { API and HTHP filtration loss } \\
\text { by } 47.5 \% \text { and } 38.8 \% \text {, } \\
\text { respectively. }\end{array}$ & [136] \\
\hline $\mathrm{T} 80 \mathrm{ZnO}$ & - $\quad$ Filtration loss & $\begin{array}{l}\text { API/HTHP } \\
\bullet \quad 80-250{ }^{\circ} \mathrm{F} \\
\bullet \quad 100-500 \text { psi }\end{array}$ & $\begin{array}{l}0.7 \mathrm{~g} \text { of } \mathrm{T} 80 \mathrm{ZnO} \text { mitigated API } \\
\text { filtration loss and HTHP } \\
\text { filtration loss by } 17 \% \text { and } 30 \% \text {, } \\
\text { respectively. }\end{array}$ & [137] \\
\hline $\mathrm{TiO}_{2}$ - Bentonite & $\begin{array}{ll}\text { - } & \text { Filtration loss } \\
\text { (API and HTHP) } \\
\text { - } & \text { Mud cake thickness }\end{array}$ & API/HTHP & $\begin{array}{l}\text { API and HTHP filtration loss } \\
\text { reduced by } 10 \% \text { and } 9.2 \% \text {, } \\
\text { respectively. }\end{array}$ & [138] \\
\hline
\end{tabular}

MWCNT = multi-walled carbon nanotubes; API = American Petroleum Institute; HTHP = high temperature high pressure; LTLP = low temperature low pressure.

\section{Lubricity of Drilling Fluids}

One of the significant characteristics of drilling fluids is lubricity. Lubricity is required in order to reduce the friction due to the continuous contact between the wellbore and drilling string in the horizontal and directional wells [139]. There are two main aspects concerning lubricity of drilling fluids, which are referred to as torque and drag. Torque refers to the frictional resistance to the rotation of the drill string, whereas drag is described as the frictional resistance to lowering and hoisting the drill string [140]. In comparison to water-based drilling fluids, it is evident that oil-based drilling fluids provide better lubricity properties [141]. Nonetheless, water-based drilling fluid is preferred compared to oil-based drilling fluids due to the use of environmental friendly fluids in the former [142]. As a result, lubricant additives are used in water-based drilling fluids with the purpose of reducing friction between the wellbore and the drill string, lowering the probability of differential pipe sticking, and increasing the drilling rate [143]. 
Farahbod et al. presented a study of the thermo-physical properties of a drilling fluid incorporated with nanoparticles to examine the capability of drilling fluids to transfer heat. The use of nanoparticles, including titanium dioxide nanoparticles and CNT, were suggested because nanoparticles possess a high specific surface area, which may increase the rate of heat transfer [144]. The study observed that drilling fluids integrated with CNT exhibited a higher percentage in the ratio of convective heat to conductive heat in comparison with fluids using the titanium dioxide nanoparticles. As such, CNT are not favored for the purpose of improving the coefficient or level of convective heat transfer. Furthermore, the study observed an increase in the rate of heat transfer and the convective heat transfer coefficient with a decrease in the average size of the titanium dioxide and $\mathrm{CNT}$, respectively. This indicates that nanoparticle size is a significant parameter to be considered in the utilization of nanoparticles in drilling fluids [145].

In drilling fluids, lubricity reduces the torque and drag force [94]. Typically, lubricity of drilling fluids is measured via torque reduction, which can be determined using the coefficient of friction (CoF). The $\mathrm{CoF}$ is defined as the ratio of the force of the friction between two bodies and the force pressing them together [146]. Ideally, a good lubricant should possess favorable properties, including high viscosity, high lubricating film strength, low flammability, low corrosion, and high solubility, and should also be non-toxic $[147,148]$. The addition of a minimal quantity of lubricants is sufficient to provide drilling fluids with adequate lubricity, as shown in Figure 12.

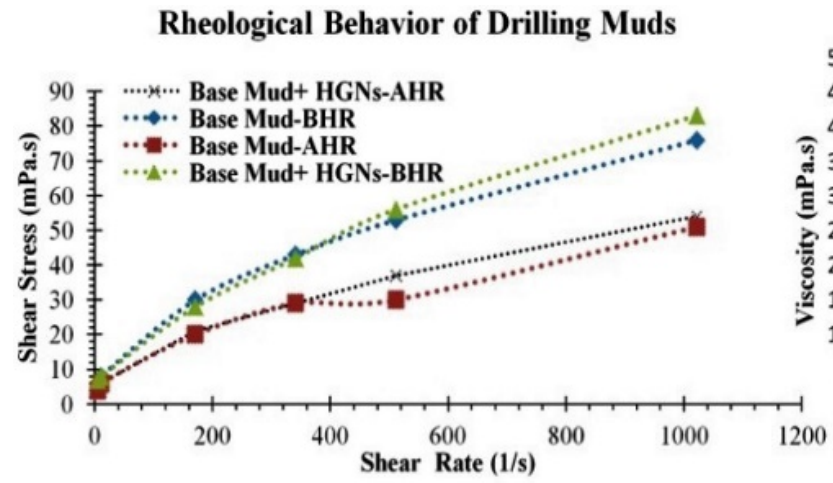

Unconsolidated

Formation Invasion of Mud Filtrate

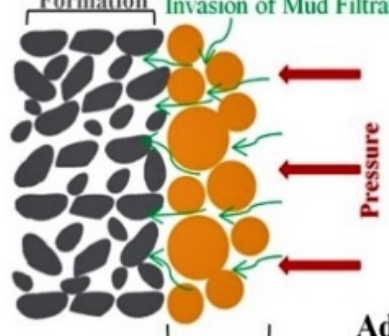

Thick Filter Cake

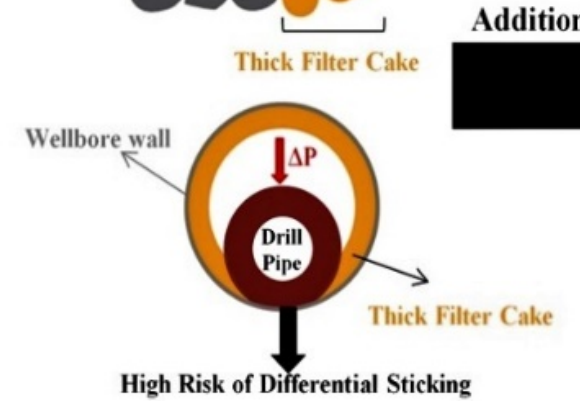

High Risk of Differential Sticking

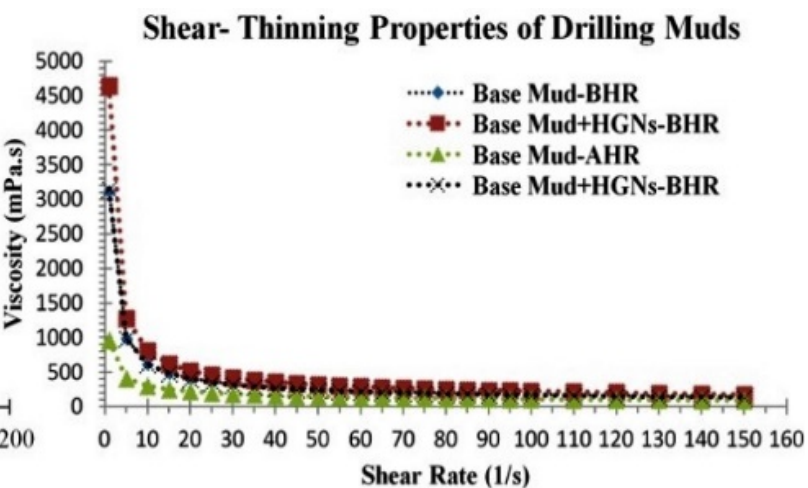

Shear Rate (1/s)

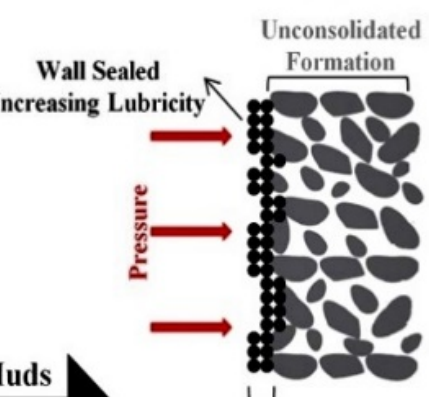

Thin Filter Cake

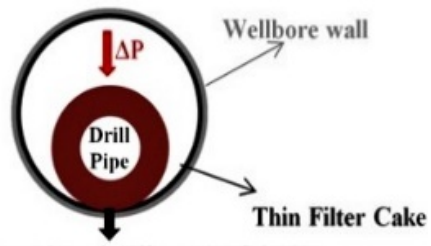

Reducing the Risk of Differential Sticking

Figure 12. Lubricity characteristics of drilling fluids using hydrophilic gilsonite nanoparticles (HGNs) for rheological properties and assessment of the sticking of the base fluids [139]. 
Husin et al. reported a torque reduction of $20 \%$ with the use of a lubricant concentration of only $1 \%$ [149]. Some of the conventionally used lubricants in drilling fluids include oils, graphite, powder, surfactant, and soaps [150].

Studies have reported various types of additives used as a lubricant for drilling fluids, including modified vegetable oils and refined polyols [151]. The combination of polyols and mud changes the wetting characteristics of the mud, causing it to behave similarly to oil mud [152]. Consequently, the lubricity and shale stability of drilling mud are considerably improved. However, polyols may also change the wettability of reservoir rocks, leading to the formation of water blocks [153]. At present, polyalkylene glycols (PAGs) and polyalphaolefins (PAOs) are the most common types of lubricant used in drilling fluids. PAOs are favored in synthetic mud due to their remarkable lubricating properties, and are applied to wellbore cleaning, shale stabilization, and bit cooling and lubrication [154]. Nonetheless, PAOs possess drawbacks, including small range of viscosity and low polarity [155].

In recent decades, there has been growing interest in the use of nanomaterials as lubricant additives. This interest has been motivated by the movement in the industry toward the use of water-based drilling fluid due to the environmental concerns associated with the use of oil-based and synthetic drilling fluids [156]. The novel properties of nanoparticles offer many potential applications, particularly to the oil and gas industry. Recently, Aftab et al. demonstrated the potential use of environmentally-friendly Tween $80 / \mathrm{ZnO}$ nanoparticles for use in drilling fluids. The approach significantly improved the lubricity and rheological properties of the drilling fluid due to the asymmetrical morphology of the nanoparticles, which eased the rotation of metal-metal surfaces and resulted in a reduced CoF [137].

Table 3 represents the variety of nanomaterials used as lubricant in water-based drilling fluids.

Table 3. Role of various nanomaterials used as lubricants in drilling fluids.

\begin{tabular}{|c|c|c|c|c|c|}
\hline Type of Nanomaterials & $\begin{array}{c}\text { Range of } \\
\text { Particle Size }\end{array}$ & $\begin{array}{c}\text { Amount of Material } \\
\text { Used (wt } \%)\end{array}$ & $\begin{array}{l}\text { Coefficient of } \\
\text { Friction }(\mathrm{CoF})\end{array}$ & CoF Reduction (\%) & References \\
\hline Graphene nanoparticles & - & $1-3 \mathrm{vol} \%$ & $0.157-0.255$ & - & [148] \\
\hline Laponite & $20 \mathrm{~nm}$ & $0-2$ & - & $11.3-32.3$ & [157] \\
\hline Carbon dots & $1-4 \mathrm{~nm}$ & $0.05-1.5$ & $0.03-0.055$ & 33 & [158] \\
\hline $\mathrm{CuO}$ nanostructures & $6-60 \mathrm{~nm}$ & 0.8 & $0.168-0.199$ & $65.4-70.9$ & [159] \\
\hline Graphene oxide & $50 \mathrm{~nm}$ & $\begin{array}{c}- \\
0.075\end{array}$ & $\begin{array}{c}0.119 \\
19.8\end{array}$ & - & $\begin{array}{l}{[142]} \\
{[160]}\end{array}$ \\
\hline $\mathrm{SiO}_{2}$ nanoparticles & $10-20 \mathrm{~nm}$ & $0.013-0.53$ & $0.24-0.38$ & $13-25$ & [161] \\
\hline $\begin{array}{c}\mathrm{TiO}_{2} / \text { API bentonite } \\
\text { nanocomposite (TNBT) }\end{array}$ & $29 \mathrm{~nm}$ & $0-1.0 \mathrm{~g}$ & $0.16-0.23$ & $33-35$ & [137] \\
\hline Gilsonite nanoparticles & $300 \mathrm{~nm}$ & $10 \mathrm{~g}$ & 0.15 & 15 & [139] \\
\hline $\begin{array}{c}\text { Polypropylene- } \mathrm{SiO}_{2} \\
\text { nanocomposite }\end{array}$ & $80-390 \mathrm{~nm}$ & & $0.23-0.28$ & 20.7 & [124] \\
\hline $\mathrm{SiO}_{2}$ nanoparticles & - & $0.5-1.5 \mathrm{ppb}$ & $0.267-0.41$ & $3.2-12.61$ & [162] \\
\hline $\begin{array}{l}\text { Xantham gum } \\
\text { (XC polymer), barite } \\
\text { and lignite }\end{array}$ & $\begin{array}{c}10-400,112,63 \\
\mathrm{~nm}\end{array}$ & $0.2-4 \mathrm{~g}$ & $0.178-0.357$ & $2.72-51.49$ & [163] \\
\hline Borate nanoparticles & $35-40 \mathrm{~nm}$ & $0.01 \mathrm{~g}$ & $0.06-0.12$ & $69-86.5$ & [164] \\
\hline $\begin{array}{l}\text { Boron Nitride }(\mathrm{BN}) \\
\text { nanoparticles }\end{array}$ & $250 \mathrm{~nm}$ & $0.05-0.20 \mathrm{~g}$ & $0.27-0.33$ & $24-37$ & [165] \\
\hline $\begin{array}{c}\text { Iron oxide }\left(\mathrm{Fe}_{2} \mathrm{O}_{3}\right) \\
\text { nanoparticles }\end{array}$ & - & $0.05-0.20 \mathrm{~g}$ & $0.147-0.170$ & $43-51$ & [165] \\
\hline
\end{tabular}


Table 3. Cont.

\begin{tabular}{|c|c|c|c|c|c|}
\hline MWCNT & $20-40 \mathrm{~nm}$ & $0.0095-0.38$ & $0.15-0.30$ & $30-50$ & [166] \\
\hline MWCNT & - & $0.01-0.04$ & $0.07-0.15$ & 62 & [167] \\
\hline $\mathrm{SiO}_{2}$ nanoparticles & - & $0.2-0.6$ & $0.35-0.38$ & - & [168] \\
\hline $\begin{array}{c}\text { Titanium oxide }\left(\mathrm{TiO}_{2}\right) \\
\text { nanoparticles }\end{array}$ & - & $0.2-0.6$ & $0.31-0.34$ & - & [168] \\
\hline $\begin{array}{c}\text { Titanium oxide }\left(\mathrm{TiO}_{2}\right) \\
\text { nanoparticles }\end{array}$ & - & $0-2.625 \mathrm{lb} / \mathrm{bbl}$ & $0.34-0.38$ & - & [169] \\
\hline Titanium Nitride (TiN) & $20 \mathrm{~nm}$ & 0.0095 & $0.311,0.546$ & 46 & [170] \\
\hline $\begin{array}{c}\text { Titanium oxide }\left(\mathrm{TiO}_{2}\right) \\
\text { nanoparticles }\end{array}$ & - & $0.5-1.0$ & $0.36-0.40$ & 14.3 & [171] \\
\hline $\begin{array}{c}\text { Boron-based } \\
\text { nanomaterial enhanced } \\
\text { additive (PQCB) }\end{array}$ & - & $1-5$ & - & $30-80$ & [172] \\
\hline $\begin{array}{c}\text { Zinc oxide nanoparticles } \\
\text { deposited acrylamide } \\
\text { composite }\end{array}$ & - & $0.1-1.0 \mathrm{~g}$ & $0.21-0.28$ & 25 & [143] \\
\hline Nanographene & & $1-5$ & $0.07-0.16$ & $34.6-54.6$ & [129] \\
\hline $\mathrm{SiO}_{2}$ nanoparticles & $1-60 \mathrm{~nm}$ & $0.5-2.0$ & $0.105-0.287$ & $22.5-71.6$ & [123] \\
\hline $\begin{array}{l}\text { Palygorskite } \\
\text { nanoparticles }\end{array}$ & $10 \mathrm{~nm}-15 \mu \mathrm{m}$ & $0-8 \mathrm{~g}$ & $0.23-0.34$ & 68 & [140] \\
\hline
\end{tabular}

\section{Challenges and Limitations}

Based on the results of recent studies, the usage of environmentally friendly additives such as bio-wastes has significantly improved the performance and functionality of drilling fluids compared to commercial GO.

However, several challenges must be addressed before these bio-wastes can be applied and commercialized at a larger scale in the oil and gas industry. One of the key issues is that raw waste materials and waste-derived nanomaterials may contain high impurities, thus necessitating an additional purification process. Therefore, future studies and exploration must be carried out to improve the yield and characterization of waste-derived nanomaterial production. A schematic illustration of the challenges related to the collection of waste materials and their recycling, and the interconnected role of consumers in society, is presented in Figure 13.

In addition, it is also important to examine novel waste derivatives by conducting aging tests and experimental studies under HPHT conditions to study the degradation of the environmentally friendly additive. In addition, the environmental impacts of wastederived nanomaterials should be highlighted. These waste additives can be added to and optimized in OBDF and SBDF formulations, in addition to those of WBDF. Furthermore, a thorough comprehensive quantitative analysis of different types of green additives and their performance can be conducted to determine the best rheological improvements. Hereafter, the role of environmentally friendly waste-derived additives will have a major role in the preparation of novel green additives for drilling fluids. It is recommended that future research focuses on identifying the green additive that optimally improves the significant rheological and filtration properties of drilling fluids. Therefore, a breakthrough can be achieved by improving the efficiency of drilling operations while reducing any harmful risks to the environment and the health of personnel. 


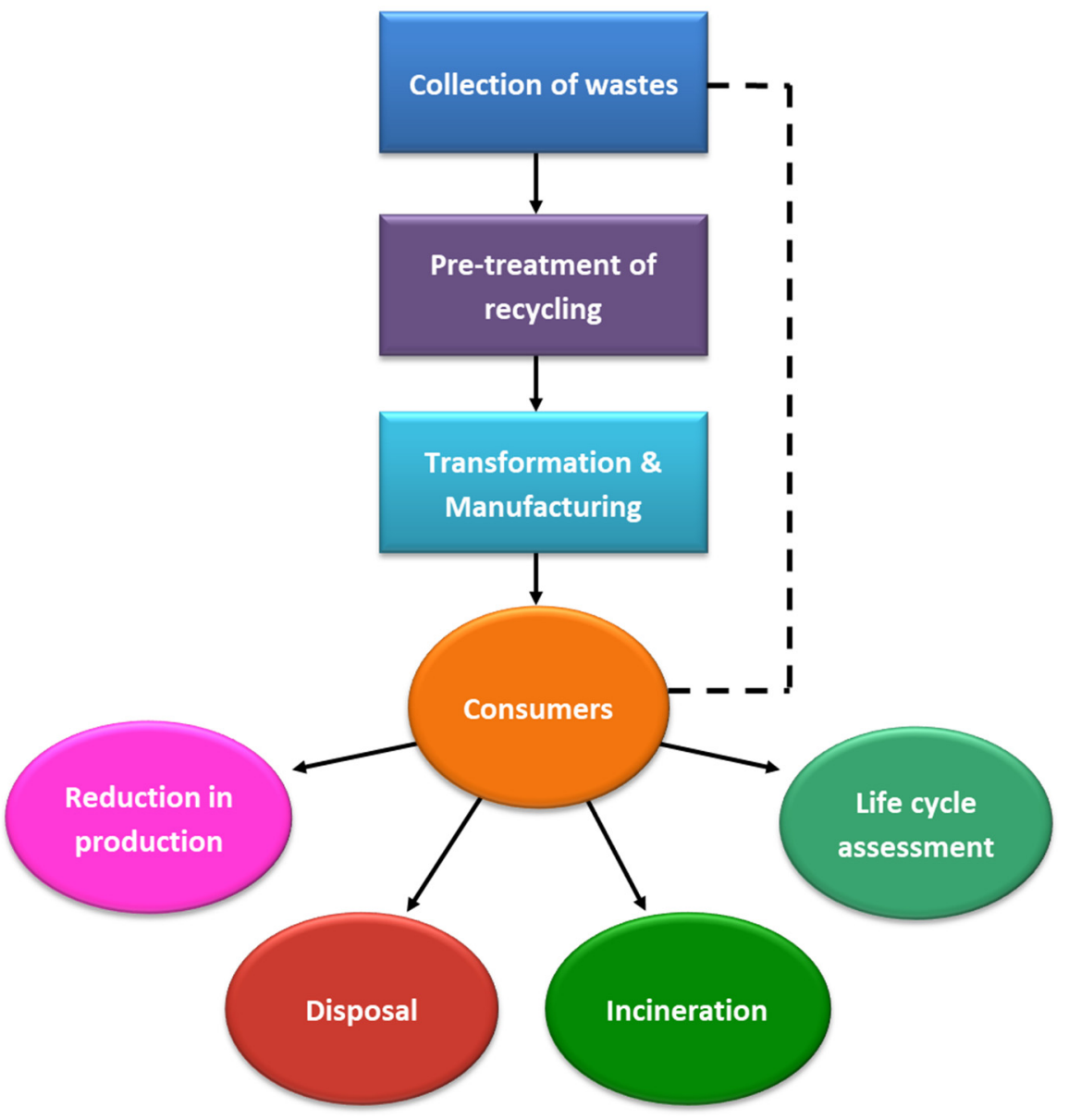

Figure 13. Schematic diagram of waste management approaches and their impacts (No ref).

Future Recommendations

To implement the use of waste-derived materials, more research is needed to achieve a better understanding for application in the oil and gas industry. Waste materials such as food waste have the potential to be utilized as an alternative to harmful and toxic additives that are conventionally used in drilling operations. To date, a variety of waste-derived materials have been explored due to their potential use as additives. These materials include food waste, such as durian rind, and plant-derived wastes, such as black sunflower seeds. The role of waste-derived nanomaterials, and the key features with the potential to improve the efficiency of drilling performance, are presented in Figure 14.

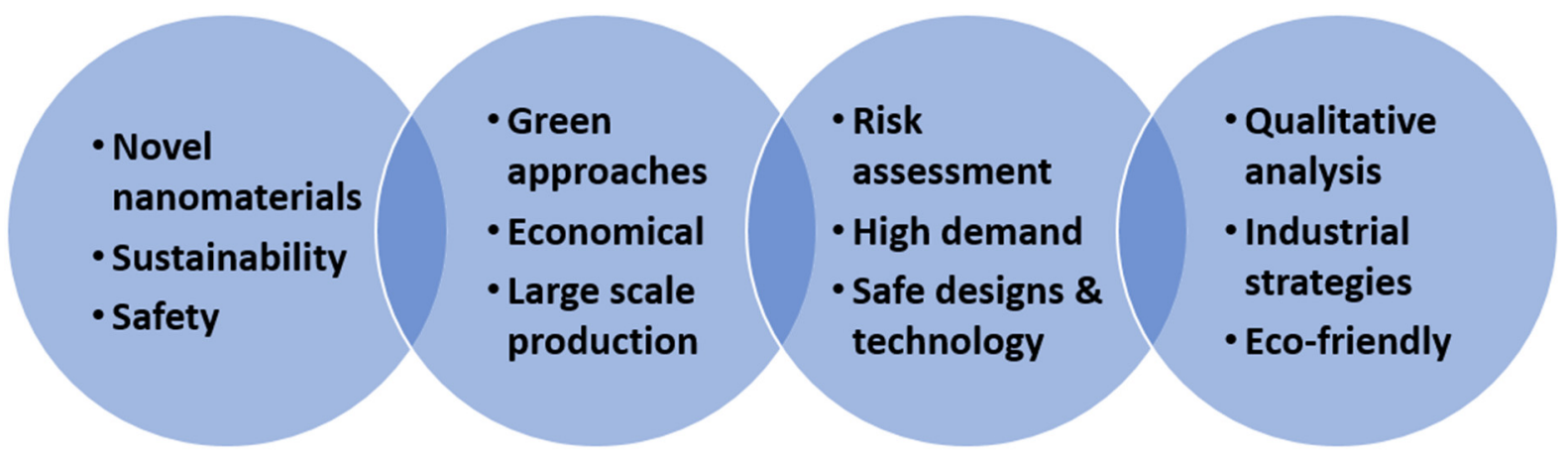

Figure 14. Strategies for future perspectives. 
Recommendations of this study are as follows:

- A comprehensive investigation of the interactions between waste-derived materials and content of drilling fluids, such as bentonite, should be undertaken.

- Cost-effectiveness of waste material usage requires more attention prior to commercialization to ensure consistency in generating drilling fluids with improved rheological properties.

- In-depth analysis is required to develop extensive methodologies for the production of additives based on waste-derived materials.

- Future studies should consider the analysis of the lubricity of drilling fluids using waste-derived materials. Extensive analysis should be undertaken to examine the morphological properties of drilling fluids.

- The potential to convert waste materials into nanomaterials, and the reproducibility of the conversion, should be considered for a variety of applications.

- A comprehensive quantitative analysis of nanomaterials used in drilling operations is necessary. Particular focus is required to determine optimum concentrations to improve conservation of resources.

- More studies should strive to investigate the mechanisms of interaction between nanomaterials and other additives present in drilling fluids.

- A comparison of drilling fluid optimization between water-based drilling fluids using nanomaterials, and synthetic and oil-based drilling fluids, should be undertaken. The comparison should be conducted in relation to conventional base fluids subjected to high temperature and pressure conditions.

\section{Conclusions}

The increased production of waste materials is a significant concern due to their effect on public health and the environment. Mismanagement of food waste, in particular, has become a major global issue, thus prompting the need for better solutions that use these materials in different applications. Among various applications, food waste can be considered to be a sustainable alternative for additives in drilling fluids used in the oil and gas drilling industry. Chemical additives to drilling fluids are necessary components to facilitate drilling operations by enhancing the fluids' properties, including rheology and filtrate loss. Studies have demonstrated that waste-derived materials, including food waste, have the potential to provide an environmentally safe alternative to toxic conventional chemical additives used in water-based drilling fluids. The materials summarized in this review include food waste and waste generated from plants. The efficiency of these materials was evaluated in terms of their effects on the yield point, plastic viscosity, filtrate loss, and mud cake thickness.

Nanomaterials are viable alternative additives for drilling fluid application. Nanomaterials can be used economically due to the small concentrations required for their efficient use in drilling fluids. Based on the summarized studies, quantities less than $1 \mathrm{~g}$ are sufficient to generate changes in the lubricity of drilling fluids. The lubricity of drilling fluids is a property that is considered to be necessary to ensure smooth drilling operations. For water-based drilling fluids, in particular, lubricant additives are required to provide better lubrication and thus reduce friction in drilling operations.

Author Contributions: R.I., original concept and initial draft of the paper, R.I. and G.K., summary of literatures, G.K. and A.S., processing and data analysis, B.M.J., supervised and coordinated the work, G.K. and R.I., funding acquisition. All authors have read and agreed to the published version of the manuscript.

Funding: The authors would like to thank Malaysia-Thailand Joint Authority (MTJA) under grant number IF062-2019, and Fundamental Research Grant Scheme FP050-2019A from the University of Malaya, for providing funds during the course of this study. This work was also supported by the National Priorities Research Program Grant No. NPRP11S-1128-170042 from the Qatar National Research Fund (member of The Qatar Foundation).

Institutional Review Board Statement: Not applicable. 
Informed Consent Statement: Not applicable.

Data Availability Statement: Not applicable.

Conflicts of Interest: The authors declare that there are no conflicts of interest regarding the publication of this manuscript.

\section{References}

1. Chen, C.; Li, C.; Reniers, G.; Yang, F. Safety and security of oil and gas pipeline transportation: A systematic analysis of research trends and future needs using WoS. J. Clean. Prod. 2021, 279, 123583. [CrossRef]

2. Li, X.; Jiang, G.; He, Y.; Chen, G. Novel starch composite fluid loss additives and their applications in environmentally friendly water-based drilling fluids. Energy Fuels 2021, 35, 2506-2513. [CrossRef]

3. Medhi, S.; Chowdhury, S.; Gupta, D.K.; Mazumdar, A. An investigation on the effects of silica and copper oxide nanoparticles on rheological and fluid loss property of drilling fluids. J. Pet. Explor. Prod. Technol. 2020, 10, 91-101. [CrossRef]

4. Zheng, Y.; Amiri, A.; Polycarpou, A.A. Enhancements in the tribological performance of environmentally friendly water-based drilling fluids using additives. Appl. Surf. Sci. 2020, 527, 146822. [CrossRef]

5. Zhang, J.; Chen, G.; Yang, N.-W.; Wang, Y.-G. Preparation of nitration-oxidation lignosulfonate as an eco-friendly drilling fluid additive. Pet. Sci. Technol. 2014, 32, 1661-1668. [CrossRef]

6. Chang, X.; Sun, J.; Xu, Z.; Lv, K.; Dai, Z.; Zhang, F.; Huang, X.; Liu, J. Synthesis of a novel environment-friendly filtration reducer and its application in water-based drilling fluids. Colloids Surf. A. 2019, 568, 284-293. [CrossRef]

7. Zhang, J.; Chen, G.; Yang, N.W.; Wang, Y.G. Preparation and evaluation of sodium hydroxymethyl lignosulfonate as eco-friendly drilling fluid additive. Adv. Mater. Res. 2012, 415, 629-632. [CrossRef]

8. de Oliveira, V.; dos Santos Alves, K.; da Silva-Junior, A.; Araújo, R.; Balaban, R.; Hilliou, L. Testing carrageenans with different chemical structures for water-based drilling fluid application. J. Mol. Liq. 2020, 299, 112139. [CrossRef]

9. Yang, M.; Luo, D.; Chen, Y.; Li, G.; Tang, D.; Meng, Y. Establishing a practical method to accurately determine and manage wellbore thermal behavior in high-temperature drilling. Appl. Energy. 2019, 238, 1471-1483. [CrossRef]

10. Ahmad, H.M.; Kamal, M.S.; Al-Harthi, M.A. High molecular weight copolymers as rheology modifier and fluid loss additive for water-based drilling fluids. J. Mol. Liq. 2018, 252, 133-143. [CrossRef]

11. Cheraghian, G.; Wu, Q.; Mostofi, M.; Li, M.-C.; Afrand, M.; Sangwai, J.S. Effect of a novel clay/silica nanocomposite on water-based drilling fluids: Improvements in rheological and filtration properties. Colloids Surf. A 2018, 555, 339-350. [CrossRef]

12. Sharma, V.P.; Mahto, V. Studies on less expansive environmentally safe polymers for development of water based drilling fluids. In SPE Asia Pacific Oil \& Gas Conference and Exhibition; OnePetro: Kuala Lumpur, Malaysia, 2006. [CrossRef]

13. Meng, X.; Zhang, Y.; Zhou, F.; Chu, P.K. Effects of carbon ash on rheological properties of water-based drilling fluids. J. Pet. Sci. Eng. 2012, 100, 1-8. [CrossRef]

14. Omotioma, M.; Ejikeme, P.; Mbah, G. Comparative analysis of the effects of cashew and mango extracts on the rheological properties of water based mud. J. Eng. Res. Appl. 2014, 4, 56-61.

15. Al-Hameedi, A.T.T.; Alkinani, H.H.; Dunn-Norman, S.; Alashwak, N.A.; Alshammari, A.F.; Alkhamis, M.M.; Mutar, R.A.; Ashammarey, A. Evaluation of environmentally friendly drilling fluid additives in water-based drilling mud. In SPE Europec Featured at 81st EAGE Conference and Exhibition; OnePetro: Kuala Lumpur, Malaysia, 2019. [CrossRef]

16. Al-Hameedi, A.T.T.; Alkinani, H.H.; Dunn-Norman, S.; Al-Alwani, M.A.; Alshammari, A.F.; Albazzaz, H.W.; Alkhamis, M.M.; Rusul, A.M.; Al-Bazzaz, W.H. Proposing a new eco-friendly drilling fluid additive to enhance the filtration properties of waterbased drilling fluid systems. In SPE Gas \& Oil Technology Showcase and Conference; OnePetro: Kuala Lumpur, Malaysia, 2019. [CrossRef]

17. Ismail, A.R.; Mohd, N.M.; Basir, N.F.; Oseh, J.O.; Ismail, I.; Blkoor, S.O. Improvement of rheological and filtration characteristics of water-based drilling fluids using naturally derived henna leaf and hibiscus leaf extracts. J. Pet. Explor. Prod. Technol. 2020, 10, 3541-3556. [CrossRef]

18. Oseh, J.O.; Norrdin, M.M.; Farooqi, F.; Ismail, R.A.; Ismail, I.; Gbadamosi, A.O.; Agi, A.J. Experimental investigation of the effect of henna leaf extracts on cuttings transportation in highly deviated and horizontal wells. J. Pet. Explor. Prod. Technol. 2019, 9, 2387-2404. [CrossRef]

19. Karakosta, K.; Mitropoulos, A.C.; Kyzas, G.Z. A review in nanopolymers for drilling fluids applications. J. Mol. Struct. 2021, 1227, 129702. [CrossRef]

20. Werner, B.; Myrseth, V.; Saasen, A. Viscoelastic properties of drilling fluids and their influence on cuttings transport. J. Pet. Sci. Eng. 2017, 156, 845-851. [CrossRef]

21. Dantas, A.; Leite, R.; Nascimento, R.; Amorim, L. The influence of chemical additives in filtration control of inhibited drilling fluids. Braz. J. Pet. Gas. 2014, 8. [CrossRef]

22. Das, B.; Chatterjee, R. Wellbore stability analysis and prediction of minimum mud weight for few wells in Krishna-Godavari Basin, India. Int. J. Rock Mech. Min. Sci. 2017, 93, 30-37. [CrossRef]

23. Ebikapaye, J. Effects of temperature on the density of water based drilling mud. J. Appl. Sci. Environ. Manag. 2018, 22, 406-408. [CrossRef] 
24. Ahmadi, M.A.; Shadizadeh, S.R.; Shah, K.; Bahadori, A. An accurate model to predict drilling fluid density at wellbore conditions. Egypt. J. Pet. 2018, 27, 1-10. [CrossRef]

25. Elkatatny, S. Enhancing the rheological properties of water-based drilling fluid using micronized starch. Arab. J. Sci. Eng. 2019, 44, 5433-5442. [CrossRef]

26. Basfar, S.; Mohamed, A.; Elkatatny, S.; Al-Majed, A. A Combined Barite-Ilmenite Weighting Material to Prevent Barite Sag in Water-Based Drilling Fluid. Materials 2019, 12, 1945. [CrossRef] [PubMed]

27. Delikesheva, D.; Syzdykov, A.K.; Ismailova, J.; Kabdushev, A.; Bukayeva, G. Measurement of the Plastic Viscosity and Yield Point of Drilling Fluids. Int. J. Eng. Res. Technol. 2020, 13, 58-65. [CrossRef]

28. Maiti, M.; Ranjan, R.; Chaturvedi, E.; Bhaumik, A.K.; Mandal, A. Formulation and characterization of water-based drilling fluids for gas hydrate reservoirs with efficient inhibition properties. J. Dispers. Sci. Technol. 2021, 42, 338-351. [CrossRef]

29. Alakbari, F.; Elkatatny, S.; Kamal, M.S.; Mahmoud, M. Optimizing the gel strength of water-based drilling fluid using clays for drilling horizontal and multi-lateral wells. In SPE Kingdom of Saudi Arabia Annual Technical Symposium and Exhibition; OnePetro: Kuala Lumpur, Malaysia, 2018. [CrossRef]

30. Mohamed, A.; Al-Afnan, S.; Elkatatny, S.; Hussein, I. Prevention of barite sag in water-based drilling fluids by a urea-based additive for drilling deep formations. Sustainability 2020, 12, 2719. [CrossRef]

31. Novriansyah, A. Experimental analysis of cassava starch as a fluid loss control agent on drilling mud. Mater. Today Proc. 2021, 39, 1094-1098.

32. Dejtaradon, P.; Hamidi, H.; Chuks, M.H.; Wilkinson, D.; Rafati, R. Impact of ZnO and CuO nanoparticles on the rheological and filtration properties of water-based drilling fluid. Colloids Surf. A 2019, 570, 354-367. [CrossRef]

33. Ali, M.; Jarni, H.H.; Aftab, A.; Ismail, A.R.; Saady, N.M.C.; Sahito, M.F.; Keshavarz, A.; Iglauer, S.; Sarmadivaleh, M. Nanomaterialbased drilling fluids for exploitation of unconventional reservoirs: A review. Energies 2020, 13, 3417. [CrossRef]

34. Bologna, M.; Aquino, G. Deforestation and world population sustainability: A quantitative analysis. Sci. Rep. 2020, 10, 7631. [CrossRef]

35. Rautela, R.; Arya, S.; Vishwakarma, S.; Lee, J.; Kim, K.-H.; Kumar, S. E-waste management and its effects on the environment and human health. Sci. Total Environ. 2021, 773, 145623. [CrossRef]

36. Castillo-Giménez, J.; Montañés, A.; Picazo-Tadeo, A.J. Performance and convergence in municipal waste treatment in the European Union. Waste Manag. 2019, 85, 222-231. [CrossRef]

37. Hoornweg, D.; Bhada-Tata, P. What a Waste: A Global Review of Solid Waste Management. 2012. Available online: https: // openknowledge.worldbank.org/handle/10986/17388 (accessed on 1 March 2012).

38. Hoornweg, D.; Bhada-Tata, P.; Kennedy, C. Environment: Waste production must peak this century. Nat. News 2013, $502,615$. [CrossRef] [PubMed]

39. Demirbas, A. Waste management, waste resource facilities and waste conversion processes. Energy Convers. Manag. 2011, 52, 1280-1287. [CrossRef]

40. Khatib, I.A. Municipal solid waste management in developing countries: Future challenges and possible opportunities. Integr. Waste Manag. 2011, 2, 35-48.

41. Gaur, V.K.; Sharma, P.; Sirohi, R.; Awasthi, M.K.; Dussap, C.-G.; Pandey, A. Assessing the impact of industrial waste on environment and mitigation strategies: A comprehensive review. J. Hazard. Mater. 2020, 398, 123019. [CrossRef] [PubMed]

42. Kumar, U.; Goonetilleke, D.; Gaikwad, V.; Pramudita, J.C.; Joshi, R.K.; Sharma, N.; Sahajwalla, V. Activated carbon from e-waste plastics as a promising anode for sodium-ion batteries. ACS Sustain. Chem. Eng. 2019, 7, 10310-10322. [CrossRef]

43. Suchorab, Z.; Franus, M.; Barnat-Hunek, D. Properties of Fibrous Concrete Made with Plastic Optical Fibers from E-Waste. Materials 2020, 13, 2414. [CrossRef]

44. Prochon, M.; Marzec, A.; Dzeikala, O. Hazardous Waste Management of Buffing Dust Collagen. Materials 2020, 13, 1498. [CrossRef]

45. Tanskanen, P. Management and recycling of electronic waste. Acta Mater. 2013, 61, 1001-1011. [CrossRef]

46. Yan, N.; Chen, X. Sustainability: Don't waste seafood waste. Nat. News 2015, 524, 155. [CrossRef]

47. Huang, Y.; Mei, L.; Chen, X.; Wang, Q. Recent developments in food packaging based on nanomaterials. Nanomaterials 2018, 8, 830. [CrossRef] [PubMed]

48. Dankwa, O.; Ackumey, S.; Amorin, R. Investigating the potential use of waste vegetable oils to produce synthetic base fluids for drilling mud formulation. In SPE Nigeria Annual International Conference and Exhibition; OnePetro: Kuala Lumpur, Malaysia, 2018. [CrossRef]

49. Al-Hameedi, A.T.T.; Alkinani, H.H.; Dunn-Norman, S.; Al-Alwani, M.A.; Alshammari, A.F.; Alkhamis, M.M.; Mutar, R.A.; Al-Bazzaz, W.H. Experimental investigation of environmentally friendly drilling fluid additives (mandarin peels powder) to substitute the conventional chemicals used in water-based drilling fluid. J. Pet. Explor. Prod. Technol. 2020, 10, 407-417. [CrossRef]

50. Al-Hameedi, A.T.T.; Alkinani, H.H.; Dunn-Norman, S.; Al-Alwani, M.A.; Alshammari, A.F.; Albazzaz, H.W.; Alkhamis, M.M.; Alashwak, N.F.; Mutar, R.A. Insights into the application of new eco-friendly drilling fluid additive to improve the fluid properties in water-based drilling fluid systems. J. Pet. Sci. Eng. 2019, 183, 106424. [CrossRef]

51. Al-Hameedi, A.T.T.; Alkinani, H.H.; Alkhamis, M.M.; Dunn-Norman, S. Utilizing a new eco-friendly drilling mud additive generated from wastes to minimize the use of the conventional chemical additives. J. Pet. Explor. Prod. Technol. 2020, 10, 3467-3481. [CrossRef] 
52. Bayat, A.E.; Moghanloo, P.J.; Piroozian, A.; Rafati, R. Experimental investigation of rheological and filtration properties of water-based drilling fluids in presence of various nanoparticles. Colloids Surf. A 2018, 555, 256-263. [CrossRef]

53. Fazelabdolabadi, B.; Khodadadi, A.A.; Sedaghatzadeh, M. Thermal and rheological properties improvement of drilling fluids using functionalized carbon nanotubes. Appl. Nanosci. 2015, 5, 651-659. [CrossRef]

54. Hassani, S.; Vu, T.N.; Rosli, N.R.; Esmaeely, S.N.; Choi, Y.-S.; Young, D.; Nesic, S. Wellbore integrity and corrosion of low alloy and stainless steels in high pressure $\mathrm{CO} 2$ geologic storage environments: An experimental study. Int. J. Greenh. Gas Control. 2014, 23, 30-43. [CrossRef]

55. Li, X.; Jiang, G.; Shen, X.; Li, G. Poly-L-arginine as a high-performance and biodegradable shale inhibitor in water-based drilling fluids for stabilizing wellbore. ACS Sustain. Chem. Eng. 2020, 8, 1899-1907. [CrossRef]

56. Ghaderi, S.; Haddadi, S.A.; Davoodi, S.; Arjmand, M. Application of sustainable saffron purple petals as an eco-friendly green additive for drilling fluids: A rheological, filtration, morphological, and corrosion inhibition study. J. Mol. Liq. 2020, 315, 113707. [CrossRef]

57. da Silva, I.G.; Lucas, E.F.; Advincula, R. On the use of an agro waste, Miscanthus x. Giganteus, as filtrate reducer for water-based drilling fluids. J. Disper. Sci. Technol. 2020,1-10. [CrossRef]

58. Joshi, P.; Goyal, S.; Singh, R.; Thakur, K. Development of water based drilling fluid using tamarind seed powder. Mater. Today Proc. 2021. [CrossRef]

59. Murtaza, M.; Tariq, Z.; Zhou, X.; Al-Shehri, D.; Mahmoud, M.; Kamal, M.S. Okra as an environment-friendly fluid loss control additive for drilling fluids: Experimental \& modeling studies. J. Pet. Sci. Eng. 2021, 204, 108743.

60. Wiśniowski, R.; Skrzypaszek, K.; Małachowski, T. Selection of a Suitable Rheological Model for Drilling Fluid Using Applied Numerical Methods. Energies 2020, 13, 3192. [CrossRef]

61. Magzoub, M.I.; Ibrahim, M.H.; Nasser, M.S.; El-Naas, M.H.; Amani, M. Utilization of Steel-Making Dust in Drilling Fluids Formulations. Processes 2020, 8, 538. [CrossRef]

62. Haile, A.; Gelebo, G.G.; Tesfaye, T.; Mengie, W.; Mebrate, M.A.; Abuhay, A.; Limeneh, D.Y. Pulp and paper mill wastes: Utilizations and prospects for high value-added biomaterials. Bioresour. Bioprocess. 2021, 8, 35. [CrossRef]

63. Zhong, H.; Gao, X.; Zhang, X.; Chen, A.; Qiu, Z.; Kong, X.; Huang, W. Minimizing the filtration loss of water-based drilling fluid with sustainable basil seed powder. Petroleum 2021. [CrossRef]

64. Rita, N.; Khalid, I.; Efras, M.R. Drilling mud performances consist of CMC made by carton waste and Na2CO3 for reducing lost circulation. Mater. Today Proc. 2021, 39, 1099-1102. [CrossRef]

65. Zhou, G.; Qiu, Z.; Zhong, H.; Zhao, X.; Kong, X. Study of Environmentally Friendly Wild Jujube Pit Powder as a Water-Based Drilling Fluid Additive. ACS Omega 2021, 6, 1436-1444. [CrossRef] [PubMed]

66. Al-Hameedi, A.T.T.; Alkinani, H.H.; Dunn-Norman, S.; Salem, E.; Knickerbocker, M.D.; Alashwak, N.F.; Mutar, R.A.; Al-Bazzaz, W.H. Laboratory Study of Environmentally Friendly Drilling Fluid Additives Banana Peel Powder for Modifying the Drilling Fluid Characteristics in Water-Based Muds. In International Petroleum Technology Conference; OnePetro: Kuala Lumpur, Malaysia, 2020. [CrossRef]

67. Okon, A.N.; Akpabio, J.U.; Tugwell, K.W. Evaluating the locally sourced materials as fluid loss control additives in water-based drilling fluid. Heliyon 2020, 6, e04091. [CrossRef]

68. Al-Hameedi, A.T.T.; Alkinani, H.H.; Dunn-Norman, S.; Alkhamis, M.M.; Feliz, J.D. Full-set measurements dataset for a waterbased drilling fluid utilizing biodegradable environmentally friendly drilling fluid additives generated from waste. Data Brief 2020, 28, 104945. [CrossRef]

69. Al-Hameedi, A.T.T.; Alkinani, H.H.; Dunn-Norman, S.; Al-Alwani, M.A.; Al-Bazzaz, W.H.; Alshammari, A.F.; Albazzaz, H.W.; Mutar, R.A. Experimental investigation of bio-enhancer drilling fluid additive: Can palm tree leaves be utilized as a supportive eco-friendly additive in water-based drilling fluid system? J. Pet. Explor. Prod. Technol. 2020, 10, 595-603. [CrossRef]

70. Al-Hameedi, A.T.T.; Alkinani, H.H.; Dunn-Norman, S.; Alashwak, N.A.; Alshammari, A.F.; Alkhamis, M.M.; W Albazzaz, H.; Mutar, R.A.; Alsaba, M.T. Environmental friendly drilling fluid additives: Can food waste products be used as thinners and fluid loss control agents for drilling fluid? In SPE Symposium: Asia Pacific Health, Safety, Security, Environment and Social Responsibility; OnePetro: Kuala Lumpur, Malaysia, 2019. [CrossRef]

71. Majid, N.F.F.; Katende, A.; Ismail, I.; Sagala, F.; Sharif, N.M.; Yunus, M.A.C. A comprehensive investigation on the performance of durian rind as a lost circulation material in water based drilling mud. Petroleum 2019, 5, 285-294. [CrossRef]

72. Wajheeuddin, M.; Hossain, M.E. Development of an environmentally-friendly water-based mud system using natural materials. Arab. J. Sci. Eng. 2018, 43, 2501-2513. [CrossRef]

73. Davoodi, S.; SA, A.R.; Jamshidi, S.; Jahromi, A.F. A novel field applicable mud formula with enhanced fluid loss properties in high pressure-high temperature well condition containing pistachio shell powder. J. Pet. Sci. Eng. 2018, 162, 378-385. [CrossRef]

74. Al-Saba, M.; Amadi, K.; Al-Hadramy, K.; Al Dushaishi, M.; Al-Hameedi, A.; Alkinani, H. Experimental investigation of biodegradable environmental friendly drilling fluid additives generated from waste. In SPE International Conference and Exhibition on Health, Safety, Security, Environment, and Social Responsibility; OnePetro: Kuala Lumpur, Malaysia, 2018. [CrossRef]

75. Hossain, M.E.; Wajheeuddin, M. The use of grass as an environmentally friendly additive in water-based drilling fluids. Pet. Sci. 2016, 13, 292-303. [CrossRef]

76. Ghazali, N.A.; Mohd, T.A.T.; Alias, N.H.; Azizi, A.; Harun, A.A. The Effect of Lemongrass as Lost Circulation Material (LCM) to the Filtrate and Filter Cake Formation; Trans Tech Publications Ltd.: Stafa-Zurich, Switzerland, 2014. [CrossRef] 
77. Okon, A.N.; Udoh, F.D.; Bassey, P.G. Evaluation of rice husk as fluid loss control additive in water-based drilling mud. In SPE Nigeria Annual International Conference and Exhibition; OnePetro: Kuala Lumpur, Malaysia, 2014. [CrossRef]

78. Azizi, A.; Ibrahim, M.S.N.; Hamid, K.H.K.; Sauki, A.; Ghazali, N.A.; Mohd, T.A.T. Agarwood waste as a new fluid loss control agent in water-based drilling fluid. Int. J. Sci. Eng. 2013, 5, 101-105. [CrossRef]

79. Adebayo, T.A.; Chinonyere, P.C. Sawdust as a filtration control and density additives in water-based drilling mud. Int. J. Sci. Eng. Res. 2012, 3, 1-2.

80. Iscan, A.; Kok, M. Effects of walnut shells on the rheological properties of water-based drilling fluids. Energy Sources Part A 2007, 29, 1061-1068. [CrossRef]

81. Alcheikh, I.; Ghosh, B. A comprehensive review on the advancement of non-damaging drilling fluids. Int. J. Petrochem. Res. 2017, 1, 61-72. [CrossRef]

82. Li, M.-C.; Wu, Q.; Lei, T.; Mei, C.; Xu, X.; Lee, S.; Gwon, J. Thermothickening Drilling Fluids Containing Bentonite and Dual-Functionalized Cellulose Nanocrystals. Energy Fuels 2020, 34, 8206-8215. [CrossRef]

83. da Câmara, P.C.; Madruga, L.Y.; Marques, N.d.N.; Balaban, R.C. Evaluation of polymer/bentonite synergy on the properties of aqueous drilling fluids for high-temperature and high-pressure oil wells. J. Mol. Liq. 2021, 327, 114808. [CrossRef]

84. Dong, W.; Pu, X.; Ren, Y.; Zhai, Y.; Gao, F.; Xie, W. Thermoresponsive bentonite for water-based drilling fluids. Materials 2019, 12, 2115. [CrossRef]

85. Abdou, M.; Al-Sabagh, A.; Ahmed, H.E.-S.; Fadl, A. Impact of barite and ilmenite mixture on enhancing the drilling mud weight. Egypt. J. Pet. 2018, 27, 955-967. [CrossRef]

86. Magzoub, M.; Mahmoud, M.; Nasser, M.; Hussein, I.; Elkatatny, S.; Sultan, A. Thermochemical upgrading of calcium bentonite for drilling fluid applications. J. Energy Res. Technol. 2019, 141, 042902. [CrossRef]

87. Karagüzel, C.; Çetinel, T.; Boylu, F.; Cinku, K.; Çelik, M. Activation of (Na, Ca)-bentonites with soda and MgO and their utilization as drilling mud. Appl. Clay Sci. 2010, 48, 398-404. [CrossRef]

88. Li, M.-C.; Wu, Q.; Han, J.; Mei, C.; Lei, T.; Lee, S.-Y.; Gwon, J. Overcoming Salt Contamination of Bentonite Water-Based Drilling Fluids with Blended Dual-Functionalized Cellulose Nanocrystals. ACS Sustain. Chem. Eng. 2020, 8, 11569-11578. [CrossRef]

89. Xie, B.; Tchameni, A.P.; Luo, M.; Wen, J. A novel thermo-associating polymer as rheological control additive for bentonite drilling fluid in deep offshore drilling. Mater. Lett. 2021, 284, 128914. [CrossRef]

90. Ikram, R.; Jan, B.M.; Ahmad, W. An overview of industrial scalable production of graphene oxide and analytical approaches for synthesis and characterization. J. Mater. Res. Technol. 2020, 9, 11587-11610. [CrossRef]

91. Qiu, X.; Zhang, Y.; Zhu, Y.; Long, C.; Su, L.; Liu, S.; Tang, Z. Applications of nanomaterials in asymmetric photocatalysis: Recent progress, challenges, and opportunities. Adv. Mater. 2021, 33, 2001731. [CrossRef] [PubMed]

92. Gong, N.; Sheppard, N.C.; Billingsley, M.M.; June, C.H.; Mitchell, M.J. Nanomaterials for T-cell cancer immunotherapy. Nat. Nanotechnol. 2021, 16, 25-36. [CrossRef]

93. Li, L.; Sun, J.S.; Xu, X.G.; Ma, C.; Yang, Y.P.; Yuan, X.B. Study and Application of Nanomaterials in Drilling Fluids. Adv. Mater. Res. 2012, 535-537, 323-328. [CrossRef]

94. Cheraghian, G. Nanoparticles in drilling fluid: A review of the state-of-the-art. J. Mater. Res. Technol. 2021, 13, 737-753. [CrossRef]

95. Shehzad, K.; Xu, Y.; Gao, C.; Duan, X. Three-dimensional macro-structures of two-dimensional nanomaterials. Chem. Soc. Rev. 2016, 45, 5541-5588. [CrossRef]

96. Hajiabadi, S.H.; Aghaei, H.; Ghabdian, M.; Kalateh-Aghamohammadi, M.; Esmaeilnezhad, E.; Choi, H.J. On the attributes of invert-emulsion drilling fluids modified with graphene oxide/inorganic complexes. J. Ind. Eng. Chem. 2021, 93, 290-301. [CrossRef]

97. Abdo, J.; Haneef, M. Nano-enhanced drilling fluids: Pioneering approach to overcome uncompromising drilling problems. J. Energy Res. Technol. 2012, 134, 014501. [CrossRef]

98. Amanullah, M.; Al-Tahini, A.M. Nano-technology-its significance in smart fluid development for oil and gas field application. In SPE Saudi Arabia Section Technical Symposium; OnePetro: Kuala Lumpur, Malaysia, 2009. [CrossRef]

99. da Luz, R.C.; Paixão, M.V.; Balaban, R.d.C. Nanosilica-chitosan hybrid materials: Preparation, characterization and application in aqueous drilling fluids. J. Mol. Liq. 2019, 279, 279-288. [CrossRef]

100. Rana, A.; Khan, I.; Saleh, T.A. Advances in Carbon Nanostructures and Nanocellulose as Additives for Efficient Drilling Fluids: Trends and Future Perspective-A Review. Energy Fuels 2021, 35, 7319-7339. [CrossRef]

101. Gautam, R.; Sahai, M.; Kumar, S. Recent advances in application of nanomaterials as additives for drilling fluids. Energy Sources Part A. 2020, 1-24. [CrossRef]

102. Ikram, R.; Mohamed Jan, B.; Vejpravova, J.; Choudhary, M.I.; Zaman Chowdhury, Z. Recent Advances of Graphene-Derived Nanocomposites in Water-Based Drilling Fluids. Nanomaterials 2020, 10, 2004. [CrossRef]

103. Kasiralvalad, E. The great potential of nanomaterials in drilling \& drilling fluid applications. Int. J. Nano Dimens. $2014,5,463-471$.

104. Li, L.; Xu, X.; Sun, J.; Yuan, X.; Li, Y. Vital role of nanomaterials in drilling fluid and reservoir protection applications. In Abu Dhabi International Petroleum Conference and Exhibition; OnePetro: Kuala Lumpur, Malaysia, 2012. [CrossRef]

105. Salih, A.; Elshehabi, T.; Bilgesu, H. Impact of nanomaterials on the rheological and filtration properties of water-based drilling fluids. In SPE Eastern Regional Meeting; OnePetro: Kuala Lumpur, Malaysia, 2016. [CrossRef]

106. Ghayedi, A.; Khosravi, A. Laboratory investigation of the effect of GO-ZnO nanocomposite on drilling fluid properties and its potential on H2S removal in oil reservoirs. J. Pet. Sci. Eng. 2020, 184, 106684. [CrossRef] 
107. Kamali, F.; Saboori, R.; Sabbaghi, S. $\mathrm{Fe}_{3} \mathrm{O}_{4}$-CMC Nanocomposite Performance Evaluation as Rheology Modifier and Fluid Loss Control Characteristic Additives in Water-Based Drilling Fluid. J. Pet. Sci. Eng. 2021, 205, 108912. [CrossRef]

108. Saboori, R.; Sabbaghi, S.; Kalantariasl, A. Improvement of rheological, filtration and thermal conductivity of bentonite drilling fluid using copper oxide/polyacrylamide nanocomposite. Powder Technol. 2019, 353, 257-266. [CrossRef]

109. Mohamadian, N.; Ghorbani, H.; Wood, D.A.; Khoshmardan, M.A. A hybrid nanocomposite of poly (styrene-methyl methacrylateacrylic acid)/clay as a novel rheology-improvement additive for drilling fluids. J. Polym. Res. 2019, 26, 33. [CrossRef]

110. Lekomtsev, A.; Keykhosravi, A.; Moghaddam, M.B.; Daneshfar, R.; Rezvanjou, O. On the prediction of filtration volume of drilling fluids containing different types of nanoparticles by ELM and PSO-LSSVM based models. Petroleum 2021. [CrossRef]

111. Rafati, R.; Smith, S.R.; Haddad, A.S.; Novara, R.; Hamidi, H. Effect of nanoparticles on the modifications of drilling fluids properties: A review of recent advances. J. Pet. Sci. Eng. 2018, 161, 61-76. [CrossRef]

112. Al-Zubaidi, N.S.; Alwasiti, A.A.; Mahmood, D. A comparison of nano bentonite and some nano chemical additives to improve drilling fluid using local clay and commercial bentonites. Egypt. J. Pet. 2017, 26, 811-818. [CrossRef]

113. Kosynkin, D.V.; Ceriotti, G.; Wilson, K.C.; Lomeda, J.R.; Scorsone, J.T.; Patel, A.D.; Friedheim, J.E.; Tour, J.M. Graphene Oxide as a High-Performance Fluid-Loss-Control Additive in Water-Based Drilling Fluids. ACS Appl. Mater. Interfaces 2012, 4, $222-227$. [CrossRef] [PubMed]

114. Sadeghalvaad, M.; Sabbaghi, S. The effect of the $\mathrm{TiO}_{2}$ / polyacrylamide nanocomposite on water-based drilling fluid properties. Powder Technol. 2015, 272, 113-119. [CrossRef]

115. Patel, A.; Stamatakis, S.; Young, S.; Friedheim, J. Advances in inhibitive water-based drilling fluids-can they replace oil-based muds? In International Symposium on Oilfield Chemistry; OnePetro: Kuala Lumpur, Malaysia, 2007. [CrossRef]

116. Vryzas, Z.; Kelessidis, V.C. Nano-based drilling fluids: A review. Energies 2017, 10, 540. [CrossRef]

117. Qu, Y.; Lai, X.; Zou, L. Polyoxyalkyleneamine as shale inhibitor in water-based drilling fluids. Appl. Clay Sci. 2009, 3, 265-268. [CrossRef]

118. Kazemi-Beydokhti, A.; Hajiabadi, S.H. Rheological investigation of smart polymer/carbon nanotube complex on properties of water-based drilling fluids. Colloids Surf. A 2018, 556, 23-29. [CrossRef]

119. Ismail, A.R.; Rashid, N.M.; Jaafar, M.Z.; Sulaiman, W.R.W.; Buang, N.A. Effect of nanomaterial on the rheology of drilling fluids. J. Appl. Sci. 2014, 14, 1192. [CrossRef]

120. Yan, X.; Kang, Y.; You, L. Wellbore instability induced by the coupling of high-pH fluid-shale reaction and fracture surface sliding in shale gas wells: Experimental and field studies. Energy Fuels 2020, 34, 5578-5588. [CrossRef]

121. Wang, K.; Jiang, G.; Li, X.; Luckham, P.F. Study of graphene oxide to stabilize shale in water-based drilling fluids. Colloids Surf. A 2020, 606, 125457. [CrossRef]

122. Aramendiz, J.; Imqam, A. Water-based drilling fluid formulation using silica and graphene nanoparticles for unconventional shale applications. J. Pet. Sci. Eng. 2019, 179, 742-749. [CrossRef]

123. Taraghikhah, S.; Kalhor Mohammadi, M.; Tahmasbi Nowtaraki, K. Multifunctional nanoadditive in water based drilling fluid for improving shale stability. In International Petroleum Technology Conference; OnePetro: Kuala Lumpur, Malaysia, 2015. [CrossRef]

124. Gbadamosi, A.O.; Junin, R.; Abdalla, Y.; Agi, A.; Oseh, J.O. Experimental investigation of the effects of silica nanoparticle on hole cleaning efficiency of water-based drilling mud. J. Pet. Sci. Eng. 2019, 172, 1226-1234. [CrossRef]

125. Al-Yasiri, M.; Awad, A.; Pervaiz, S.; Wen, D. Influence of silica nanoparticles on the functionality of water-based drilling fluids. J. Pet. Sci. Eng. 2019, 179, 504-512. [CrossRef]

126. Medhi, S.; Gupta, D.; Sangwai, J.S. Impact of zinc oxide nanoparticles on the rheological and fluid-loss properties, and the hydraulic performance of non-damaging drilling fluid. J. Nat. Gas Sci. Eng. 2021, 88, 103834. [CrossRef]

127. Halali, M.A.; Ghotbi, C.; Tahmasbi, K.; Ghazanfari, M.H. The role of carbon nanotubes in improving thermal stability of polymeric fluids: Experimental and modeling. Ind. Eng. Chem. Res. 2016, 55, 7514-7534. [CrossRef]

128. Barry, M.M.; Jung, Y.; Lee, J.-K.; Phuoc, T.X.; Chyu, M.K. Fluid filtration and rheological properties of nanoparticle additive and intercalated clay hybrid bentonite drilling fluids. J. Pet. Sci. Eng. 2015, 127, 338-346. [CrossRef]

129. Taha, N.M.; Lee, S. Nano graphene application improving drilling fluids performance. In International Petroleum Technology Conference; OnePetro: Kuala Lumpur, Malaysia, 2015. [CrossRef]

130. Özkan, A. Effect of gold nanoparticle functionalized multi-walled carbon nanotubes on the properties of Na-bentonite water based drilling fluid. Fresenius Environ. Bull. 2020, 29, 143-151.

131. Mohideen, A.A.M.; Saheed, M.S.M.; Mohamed, N.M. Multiwalled carbon nanotubes and graphene oxide as nano-additives in water-based drilling fluid for enhanced fluid-loss-control \& gel strength. In AIP Conference Proceedings; AIP Publishing LLC: New York, NY, USA, 2019. [CrossRef]

132. Elochukwu, H.; Sia, L.K.S.; Gholami, R.; Hamid, M.A. Data on experimental investigation of Methyl Ester Sulphonate and nanopolystyrene for rheology improvement and filtration loss control of water-based drilling fluid. Data Brief 2018, 21, 972-979. [CrossRef] [PubMed]

133. Abdo, J.; AL-Sharji, H.; Hassan, E. Effects of nano-sepiolite on rheological properties and filtration loss of water-based drilling fluids. Surf. Interface Anal. 2016, 48, 522-526. [CrossRef]

134. Medhi, S.; Chowdhury, S.; Bhatt, N.; Gupta, D.K.; Rana, S.; Sangwai, J.S. Analysis of high performing graphene oxide nanosheets based non-damaging drilling fluids through rheological measurements and CFD studies. Powder Technol. 2021, 377, 379-395. [CrossRef] 
135. Ma, J.; Pang, S.; Zhang, Z.; Xia, B.; An, Y. Experimental Study on the Polymer/Graphene Oxide Composite as a Fluid Loss Agent for Water-Based Drilling Fluids. ACS Omega 2021, 6, 9750-9763. [CrossRef]

136. Davoodi, S.; SA, A.R.; Soleimanian, A.; Jahromi, A.F. Application of a novel acrylamide copolymer containing highly hydrophobic comonomer as filtration control and rheology modifier additive in water-based drilling mud. J. Pet. Sci. Eng. 2019, 180, 747-755. [CrossRef]

137. Aftab, A.; Ali, M.; Arif, M.; Panhwar, S.; Saady, N.M.C.; Al-Khdheeawi, E.A.; Mahmoud, O.; Ismail, A.R.; Keshavarz, A.; Iglauer, S. Influence of tailor-made $\mathrm{TiO}_{2}$ / API bentonite nanocomposite on drilling mud performance: Towards enhanced drilling operations. Appl. Clay Sci. 2020, 199, 105862. [CrossRef]

138. Nizamani, A.; Ismail, A.R.; Junin, R.; Dayo, A.; Tunio, A.; Ibupoto, Z.; Sidek, M. Synthesis of titaniabentonite nano composite and its applications in water-based drilling fluids. Chem. Eng. Trans. 2017, 56, 949-954.

139. Pakdaman, E.; Osfouri, S.; Azin, R.; Niknam, K.; Roohi, A. Improving the rheology, lubricity, and differential sticking properties of water-based drilling muds at high temperatures using hydrophilic Gilsonite nanoparticles. Colloids Surf. A 2019, 582, 123930. [CrossRef]

140. Abdo, J.; Haneef, M. Clay nanoparticles modified drilling fluids for drilling of deep hydrocarbon wells. Appl. Clay Sci. 2013, 86, 76-82. [CrossRef]

141. Ma, J.; Xu, J.; Pang, S.; Zhou, W.; Xia, B.; An, Y. Novel Environmentally Friendly Lubricants for Drilling Fluids Applied in Shale Formation. Energy Fuels 2021, 35, 8153-8162. [CrossRef]

142. Kusrini, E.; Oktavianto, F.; Usman, A.; Mawarni, D.P.; Alhamid, M.I. Synthesis, characterization, and performance of graphene oxide and phosphorylated graphene oxide as additive in water-based drilling fluids. Appl. Surf. Sci. 2020, 506, 145005. [CrossRef]

143. Aftab, A.; Ismail, A.R.; Khokhar, S.; Ibupoto, Z.H. Novel zinc oxide nanoparticles deposited acrylamide composite used for enhancing the performance of water-based drilling fluids at elevated temperature conditions. J. Pet. Sci. Eng. 2016, 146, $1142-1157$. [CrossRef]

144. Farahbod, F. Experimental investigation of thermo-physical properties of drilling fluid integrated with nanoparticles: Improvement of drilling operation performance. Powder Technol. 2021, 384, 125-131. [CrossRef]

145. William, J.K.M.; Gupta, P.; Sangwai, J.S. Interaction of lubricants on the rheological and filtration loss properties of water-based drilling fluids. Pet. Sci. Technol. 2021, 39, 235-248. [CrossRef]

146. Zheng, Y.; Asif, A.; Amiri, A.; Polycarpou, A.A. Graphene-Based Aqueous Drilling Muds as Efficient, Durable, and Environmentally Friendly Alternatives for Oil-Based Muds. ACS Appl. Nano Mater. 2021, 4, 1243-1251. [CrossRef]

147. Kania, D.; Yunus, R.; Omar, R.; Rashid, S.A.; Jan, B.M. A review of biolubricants in drilling fluids: Recent research, performance, and applications. J. Pet. Sci. Eng. 2015, 135, 177-184. [CrossRef]

148. Perumalsamy, J.; Gupta, P.; Sangwai, J.S. Performance evaluation of esters and graphene nanoparticles as an additives on the rheological and lubrication properties of water-based drilling mud. J. Pet. Sci. Eng. 2021, 204, 108680. [CrossRef]

149. Lescure, J.; Teng, J.; Degouy, D.; Espagne, B.J.-L. Development and field trial of a non-aqueous-based mud lubricant. In SPE Offshore Europe Oil and Gas Conference and Exhibition; OnePetro: Kuala Lumpur, Malaysia, 2013. [CrossRef]

150. Husin, H.; Elraies, K.A.; Choi, H.J.; Aman, Z. Influence of Graphene Nanoplatelet and Silver Nanoparticle on the Rheological Properties of WaterBased Mud. Appl. Sci. 2018, 8, 1386. [CrossRef]

151. Owuna, F.; Dabai, M.; Sokoto, M.; Dangoggo, S.; Bagudo, B.; Birnin-Yauri, U.; Hassan, L.; Sada, I.; Abubakar, A.; Jibrin, M. Chemical modification of vegetable oils for the production of biolubricants using trimethylolpropane: A review. Egypt. J. Pet. 2020, 29, 75-82. [CrossRef]

152. Zainal, N.; Zulkifli, N.; Gulzar, M.; Masjuki, H. A review on the chemistry, production, and technological potential of bio-based lubricants. Renew. Sustain. Energy Rev. 2018, 82, 80-102. [CrossRef]

153. Syahir, A.; Zulkifli, N.; Masjuki, H.; Kalam, M.; Alabdulkarem, A.; Gulzar, M.; Khuong, L.; Harith, M. A review on bio-based lubricants and their applications. J. Clean. Prod. 2017, 168, 997-1016. [CrossRef]

154. Kumar, H.; Harsha, A. Enhanced Lubrication Ability of Polyalphaolefin and Polypropylene Glycol by COOH-Functionalized Multiwalled Carbon Nanotubes as an Additive. J. Mater. Eng. Perform. 2021, 30, 1075-1089. [CrossRef]

155. Liu, X.; Chen, Y. Synthesis of polyethylene glycol modified carbon dots as a kind of excellent water-based lubricant additives. Fullerenes, Nanotubes Carbon Nanostruct. 2019, 27, 400-409. [CrossRef]

156. Idress, M.; Hasan, M.L. Investigation of Different Environmental-Friendly Waste Materials as Lost Circulation Additive in Drilling Fluids; Springer: Berlin, Germany, 2020; pp. 233-242. [CrossRef]

157. Huang, X.-B.; Sun, J.-S.; Huang, Y.; Yan, B.-C.; Dong, X.-D.; Liu, F.; Wang, R. Laponite: A promising nanomaterial to formulate high-performance water-based drilling fluids. Pet. Sci. 2021, 18, 579-590. [CrossRef]

158. Tang, J.; Chen, S.; Jia, Y.; Ma, Y.; Xie, H.; Quan, X.; Ding, Q. Carbon dots as an additive for improving performance in water-based lubricants for amorphous carbon (aC) coatings. Carbon 2020, 156, 272-281. [CrossRef]

159. Zhao, J.; Yang, G.; Zhang, Y.; Zhang, S.; Zhang, C.; Gao, C.; Zhang, P. Controllable synthesis of different morphologies of CuO nanostructures for tribological evaluation as water-based lubricant additives. Friction 2021, 9, 963-977. [CrossRef]

160. Liu, S.; Chen, Z.; Meng, Q.; Zhou, H.; Li, C.; Liu, B. Effect of graphene and graphene oxide addition on lubricating and friction properties of drilling fluids. Nanosci. Nanotechnol. Lett. 2017, 9, 446-452. [CrossRef]

161. Mohamed, A.; Dahab, A.-S.A.; Shokir, E. Enhancement of Water-Based Mud Rheology and Lubricity Using Silica Nanoparticles. Pet. Coal. 2020, 62, 1427-1434. 
162. Katende, A.; Boyou, N.V.; Ismail, I.; Chung, D.Z.; Sagala, F.; Hussein, N.; Ismail, M.S. Improving the performance of oil based mud and water based mud in a high temperature hole using nanosilica nanoparticles. Colloids Surf. A 2019, 577, 645-673. [CrossRef]

163. Alwasitti, A.A.; Al-Zubaidi, N.S.; Salam, M. Enhancing lubricity of drilling fluid using nanomaterial additives. Pet. Coal. 2019, 61.

164. Saffari, H.; Soltani, R.; Alaei, M.; Soleymani, M. Tribological properties of water-based drilling fluids with borate nanoparticles as lubricant additives. J. Pet. Sci. Eng. 2018, 171, 253-259. [CrossRef]

165. Alvi, M.A.A.; Belayneh, M.; Saasen, A.; Aadnøy, B.S. The effect of micro-sized boron nitride $\mathrm{BN}$ and iron trioxide $\mathrm{Fe}_{2} \mathrm{O}_{3}$ nanoparticles on the properties of laboratory bentonite drilling fluid. In SPE Norway One Day Seminar; OnePetro: Kuala Lumpur, Malaysia, 2018. [CrossRef]

166. Akram, A.; Alvi, M.A.A.; Belayneh, M. The Impact of MWCNT on XG Polymer/Salt Treated Laboratory Water Based Drilling Fluid. Int. J. Nano Sci. Nanotechnol. 2018, 9, 1-8.

167. Ismail, A.; Rashid, M.; Thameem, B. Application of nanomaterials to enhanced the lubricity and rheological properties of water based drilling fluid. In IOP Conference Series: Materials Science and Engineering; IOP Publishing: New York, NY, USA, 2018. [CrossRef]

168. Bég, O.A.; Espinoza, D.S.; Kadir, A.; Shamshuddin, M.; Sohail, A. Experimental study of improved rheology and lubricity of drilling fluids enhanced with nano-particles. Appl. Nanosci. 2018, 8, 1069-1090. [CrossRef]

169. Parizad, A.; Shahbazi, K.; Tanha, A.A. Enhancement of polymeric water-based drilling fluid properties using nanoparticles. J. Pet. Sci. Eng. 2018, 170, 813-828. [CrossRef]

170. Vegard, B.; Belayneh, M. The Effect Of Titanium Nitride (TiN) Nanoparticle On The Properties \& Performance Bentonite Drilling Fluid. Int. J. Nano Sci. Nanotechnol. 2017, 8, 25-35.

171. Mijić, P.; Gaurina-Međimurec, N.; Pašić, B. The Influence of $\mathrm{SiO}_{2}$ and $\mathrm{TiO}_{2}$ Nanoparticles on the Properties of Water-Based Mud. In International Conference on Offshore Mechanics and Arctic Engineering; American Society of Mechanical Engineers: New York, NY, USA, 2017. [CrossRef]

172. Krishnan, S.; Abyat, Z.; Chok, C. Characterization of boron-based nanomaterial enhanced additive in water-based drilling fluids: A study on lubricity, drag, ROP and fluid loss improvement. In SPE/IADC Middle East Drilling Technology Conference and Exhibition; OnePetro: Kuala Lumpur, Malaysia, 2016. [CrossRef] 